\title{
MATRILINEAL INHERITANCE AND MIGRATION IN A MINANGKABAU COMMUNITY
}

\author{
R. J. Chadwick
}

\section{Minangkabau and Marantau}

The matrilineal and uxorilocal Minangkabau population of West Sumatra is composed of about five hundred self-contained communities called nagari. These communities are geographically discrete, largely endogamous, and formerly self-governing. ${ }^{1}$ Each nagari has a specific ecological and economic adaptation according to its situation at home ${ }^{2}$ and produces a specific adaptation to city life among its very large emigré population.

Migration from one's home nagari to another area is called marantau. Marantau is an ancient trend among the Minangkabau, ${ }^{3}$ is intrinsic to immemorial social process, and is functionally implicated in the social structure of villages in the homeland. But even in the

\footnotetext{
${ }^{1}$ During my first fieldwork in Minangkabau, Koto Anu, the community I researched, did not constitute an administrative unit in its own right. Together with a distant neighbor, the nagari Koto Apo, it was one part of an artificially created administrative unit, the kenegarian of Kaduo Koto (the two settlements). Under Dutch rule, it constituted one of the six communities in a different administrative unit, the lareh of Anam Koto (six settlements). Neither lareh nor kenegarian were perceived as having any sociological relevance for Koto Anu people. (Like Koto Anu, the names Koto Apo, Kaduo Koto, and Anam Koto are pseudonyms.) The Village Law of 1979 (see Tsuyoshi Kato, "Different Fields, Similar Locusts: Adat Communities and The Village Law of 1979 in Indonesia" Indonesia 20: 89-114) constituted Koto Anu as a minimal administrative unit (desa) for the first time in living memory and thus redressed the situation for Koto Anu people, at least. Since this law was enacted there have been grumblings of discontent in West Sumatra as elsewhere; other communities have not fared as well as Koto Anu, finding themselves broken into smaller divisions that are sociologically inappropriate from the point of view of the people living in those communities.

2 For example, the village described in J. Kahn, Minangkabau Social Formations (Cambridge: Cambridge University press, 1980) specializes in blacksmithing and the forging of iron implements.

${ }^{3}$ See Mochtar Naim, Merantau: pola migrasi suku Minangkabau (Jogjakarta: Gajah Mada University Press, 1979); and Tsuyoshi Kato, Matriliny and Migration (Ithaca, N.Y.: Cornell University Press, 1982). Both authors deal with marantau for West Sumatra as a whole. The approach taken in this article differs from that of other authors in that I have looked closely at one community only. Therefore, any generalizations in time and place made from this data should be understood as hypotheses yet to be tested against a wider range of communities.
} 
space of a decade, one can observe that the functional relationship between matriliny and migration is dynamic and constantly evolving.

\section{Homeland and Diaspora}

The Minangkabau population perceives itself as dispersed over two mutually exclusive areas, a homeland (the present province of West Sumatra), on the one hand, and the remainder of the Malay/Indonesian world wherever representatives of the Minangkabau diaspora are to be found, on the other. This latter area is called the rantau. The verb marantau is derived from the noun rantau, which may be loosely translated as "(a) foreign shore(s)." The verb marantau, therefore, means "to go abroad."

Legend has it that the founders of Minangkabau descended from the volcano Marapi (the burning or fiery mountain) either directly from its crater or from a ship that landed there in a time of flood when the peak showed as no more than the size of an egg and spread from there into the surrounding slopes and valleys. This area covering the slopes of several prominent volcanoes and the intervening valleys and plains (known to the Dutch colonizers as the Padang Highlands) is known colloquially in Minangkabau as the darek. Darek generally means "high land above water," that is, the land up and beyond the immediate shores of a river, lake, or sea. The darek is composed of three central districts called the three luhak.

Following the legendary dispersal of the Minangkabau forebears from the peak of Mount Marapi into the three districts of ancient settlement, a further wave of settlement was said to have spread Minangkabau into three peripheral areas, one associated with each of the three central districts and known as the three rantau (shores). In addition to the three luhak and the three associated rantau, the Minangkabau also count the west coast of central Sumatra as part of their immemorially traditional territory. This coast is known as the pasisia (coast), and it is from this direction that Islam is said to have entered Minangkabau mediated by Achenese traders. The darek is seen as the center of authority for immemorial custom (adat), and the pasisia is seen as a frontier that the Islamic religion (agama, or syarak) has crossed to penetrate to the high interior. The interaction and mutual penetration of custom and Islam has been continuously problematic for the Minangkabau, no less than for anthropologists, and the apparently never-ending dialectic between them is summed up in a proverb that says, "Islam goes uphill, and custom descends [the hills]" (syarak mandaki: adaik manurun).

It seems that a further wave of agricultural pioneering occurred beyond the three traditional rantau, for beyond the borders of West Sumatra long-established populations claim Minangkabau descent. This outer zone of agricultural pioneering is also known as rantau, although it is not part of the ancient homelands in the same way that the three traditional rantau are.

In addition, Minangkabau emigrants have, since early historic times, been attracted to urban areas, mainly on the east coast of Sumatra, where trade and wage-labor opportunities are found. In this century, and especially since the end of World War II, movement to the urban areas of Sumatra has been greatly accelerated. These areas are also known as rantau, so that even rural-urban migration has come to be known as marantau.

In the 1970s and 1980s, the proportion of emigrants who have gone beyond the confines of Sumatra has dramatically increased. Significant numbers of Minangkabau people and their children and grandchildren are found throughout the Indonesian archipelago. The largest concentrations of the Minangkabau diaspora are found in the bigger towns and cities 
of Indonesia for the Minangkabau excel in petty trade and migrate to wherever they think they can improve their standards of living.

Thus the term rantau has now acquired an unprecedented comprehensiveness. Whereas it may once have referred mainly to the shores of the rivers rising in the darek, and the shoreline of Sumatra, it now refers to wherever Minangkabau emigrants choose to go in search of a living and could be translated simply as "(a) foreign shore(s)." The rantau now includes destinations beyond the Indonesian Archipelago and the Malaysian Peninsula.

The map in figure 1 (Minangkabau: Heartland and Diaspora) attempts to synthesize information from several sources to summarize the preceding paragraphs graphically. 4

\section{The Heartland}

I conducted research in a village in the heartland of Minangkabau, Koto Anu (a pseudonym) in 1974-1975 and follow-up research in $1986 . .^{5}$ On the basis of fieldwork in one community in the 1970s and 1980s I formulated a number of general hypotheses about Minangkabau. Whether the observations I recorded apply more widely in Minangkabau and whether they have any application to the situation thirty or forty years ago are things that only further research by historians and other ethnographers can determine.

The landscape in the heartland varies continuously, allowing both wet-rice cultivation in the valleys and longer slopes, hill crops on the ridges and steeper unirrigated country, and the extraction of forest products from primary forest. Numerous streams and rivers, some large highland lakes, and the adjacent ocean on the west coast provide ample fish. Each nagari economy is adapted to its own mixture of these and other ingredients.

In the eleven years between my first fieldwork and my second census of a highland village, the highland towns have not changed much; but the coastal capital of Padang has tripled in population. Towns always play a vital role in peasant life, but in the last decade, the city of Padang seems to have started to replace non-Minangkabau cities as a destination for marantau.

\section{The Ecology and Economy of Koto Anu}

Koto Anu is situated on the shores of a large lake in the highland interior of West Sumatra. It is one of a score of such villages around the shore of the lake. The lake itself nestles in a very ancient volcano-tectonic caldera. The caldera has mountainous walls surrounding a lake $70 \mathrm{~km}$ in circumference. The lake is bordered by a strip of land that slopes down from the bottom of the steep walls of the caldera to the lake's edge. This littoral is drained by numerous streams that form on the mountain slopes and discharge into the lake.

\footnotetext{
${ }^{4}$ One would normally avoid sweeping generalizations about marantau as a panhistoric phenomenon and cultural category in Minangkabau were it not for the fact the Minangkabau themselves see marantau as an ancient trend in their society, a belief that is underwritten by the traditional geography of their world. According to $\mathrm{M}$. D. Mansoer et al., Sedjarah Minangkabau (Jakarta: Bhratara, 1970), "Pergi merantau mempunjai arti dan effek sosial-ekonomis dan sosial-kulturil bagi Minangkabau dan penduduknja, dari zaman dahulu hingga dewasa ini."

5 Both of my field trips to Koto Anu were sponsored by Lembaga Ilmu-Pengetahuan Indonesia (the Indonesian Academy of Sciences); the second trip was also sponsored by Andalas University in Padang, West Sumatra. In the intervening years, I made many short social visits to Minangkabau while working with Minangkabau informants in Western Australia on Minangkabau language and literature. I wish to thank in particular Datuak Sinaro Alam, Drs Syafnir Abunain and Emwady Noerdin S. H. for their help in my research. I also owe a tremendous debt to the public of Koto Anu (a pseudonym for the village where I conducted my research) for their tremendous hospitality and tolerance when I was doing the rounds of the four hundred houses there.
} 


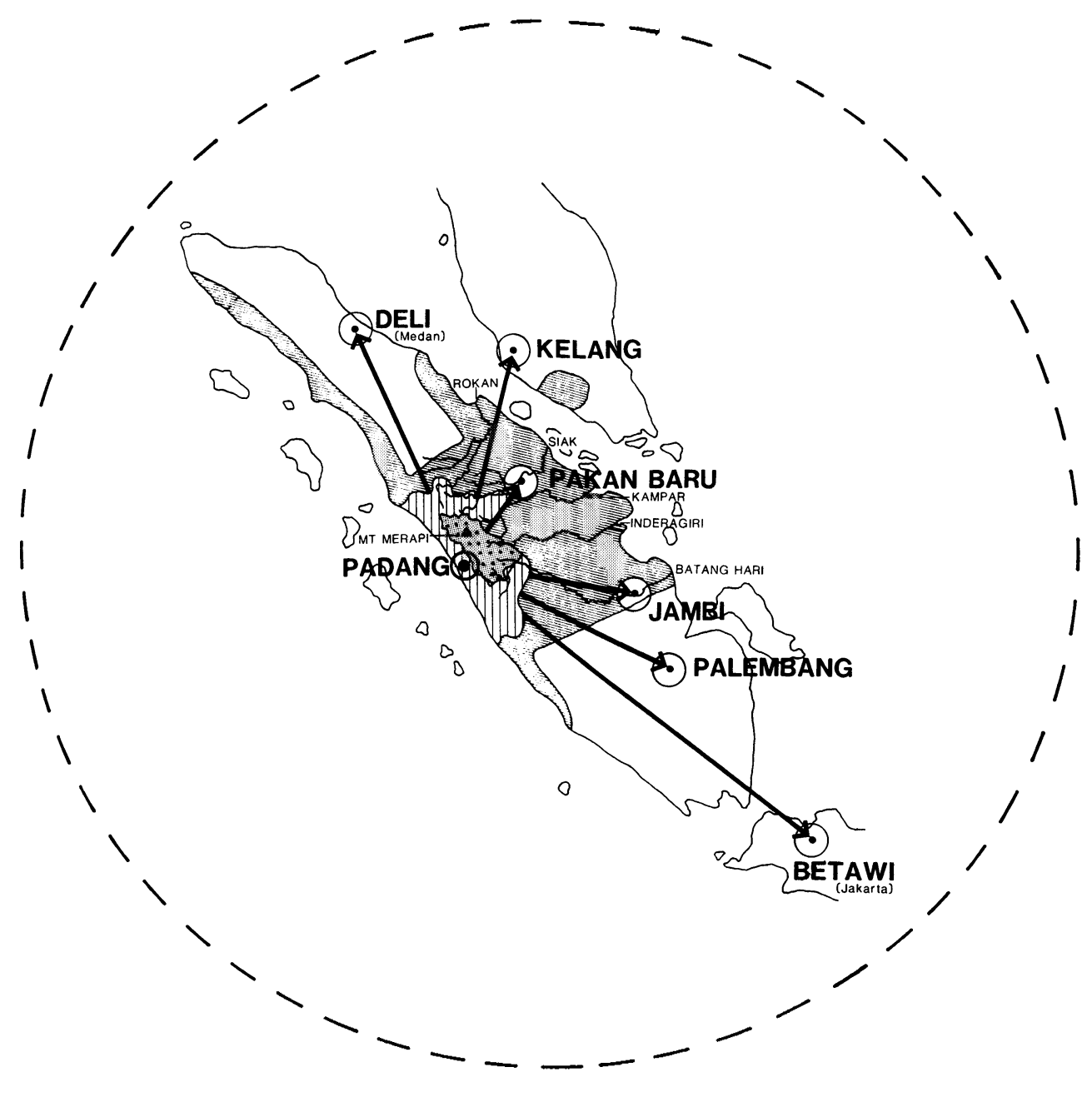

2::2 The three Iuhak

[1] The three traditional rantau areas

I Later rantau areas (agricultural pioneering)

$\rightarrow$ Twentieth Century urban rantau destinations

Fig. 1. MINANGKABAU: HMELAND AND DIASPORA

Sources: Mochtar Naim, Merantau: Pola migrasi suku Minangkabau (Jogjakarta: Gajah Mada University Press, 1979), p. 64; Tsuyoshi Kati, Matriliny and Migration (Ithaca, N.Y.: Cornell University Press, 1982), pp. 21, 37; Christine Dobbin, Islamic Revivalism in a Changing Peasant Economy: Central Sumatra, 1984-1847 (London: Curzon Press, 1983), pp. 254 ff. 
The width of this gently sloping plain, which is eminently suitable for wet-rice cultivation, varies from about $2 \mathrm{~km}$ at its greatest extent in Koto Anu to about $100 \mathrm{~m}$ on the other side of the lake. The width of the littoral has determined the particular ecological and economic adaptation of the various nagari strung around the lake. Ecological adaptation varies from an almost exclusive concentration on rice in Koto $\mathrm{Anu}$, where the flats are broadest, to an almost exclusive focus on orchards where the flats are mainly occupied by houses and a road. Between these two extremes, the degree to which the agriculture of a village is mixed varies continuously. The differentiation of communities around the shores of the lake is representative of the most important dimension of ecological variation among Minangkabau villages.

The hill crops grown in Koto Anu include cinnamon, nutmeg, coffee, and tropical fruits. Besides rice and orchards the villagers raise stock, fish, and grow vegetables.

The economy of Koto Anu is not entirely agricultural: there are shopkeepers, tailors, barbers, carpenters, schoolteachers, and so on, and some people engage in traditional crafts such as pandanus weaving. In addition, the economy is supported by a significant net inflow of money orders and other contributions from the rantau. Koto Anu is a culturally conservative community by Minangkabau standards: it has a rich ceremonial life and 85 percent of its population practice a conservative form of Islam, having failed to join the reform movement that swept the area many years ago.

\section{Social Structure, Demography, and Migration in Koto Anu}

The nagari is a closed and corporate unit with the segmentary structure typical of unilineal kinship systems. Surprisingly, it retains these characteristics in modern times when more than half the people claiming membership of the nagari are dispersed throughout the Indonesian archipelago.

The autonomy of Minangkabau communities led certain early Dutch writers to refer to them as "village republics." Today, the state has assumed many of the functions of social control, but the council of chiefs still plays an important role in ceremonial requirements and as a forum for communitywide concerns.

The largest grouping below the nagari level is the suku (clan, literally "quarter"). There are six clans in Koto Anu. Membership is by matrilineal descent or adoption, and the clan is strictly exogamous. Members of a clan are regarded as honorary kin, although it is conceded that the constituent subclans may have distinct genealogical origins, having arrived there "from the slopes of Mount Marapi" independently of each other. Each clan is divided into a number of payuang (subclans, literally "umbrellas") each with its own consensually elected headman. Members of a subclan consider themselves to be quite closely related, although the exact manner of relationship is rarely known. In turn, each subclan is composed of a number of genealogical isolates (lineages) of varying degrees of size, genealogical depth, and extension, whose boundaries are not as stable as those of the clan and subclan. There is no native term for the genealogical isolate. These lineages, in turn, are composed of one or more discrete genealogical segments known as sa-buah paruik (one womb), which I will refer to in this article as "land-holding corporations."

There are twenty-eight subclans in Koto Anu distributed across the six clans. The size of a subclan is significantly correlated with the intensity of migration from it, ${ }^{6}$ which suggests that migration is partly a response to pressure of numbers on resources.

\footnotetext{
${ }^{6}$ See R. J. Chadwick, "Marantau: Aspects of Outmigration from a West Sumatran Village" (Master's thesis, University of Western Australia, 1976), p. 70.
} 
Between the census of 1961 and that of 1970, the population of Kaduo Koto, the confederation of two neighboring nagari, of which Koto Anu is one, remained static, showing no increase in line with significant nationwide population growth. ${ }^{7}$ In 1975 , the population with a claim to residence in Koto Anu, whether born there or, as with many of the younger generation, born in the rantau was about five thousand, of which more than half were resident in the rantau. ${ }^{8}$ Overall the profile for the total population shows much the same characteristics as Widjojo's projections for the Indonesian population in $1976 .{ }^{9}$ But the structures of the two constituent parts, nagari and rantau, are strikingly different: the nagari population is a relatively aged and feminine segment of the total population. ${ }^{10}$

The concept of marantau, as understood by the Koto Anu population, comprises both marantau dakek (nearby migration, or migration within the heartland) and marantau jauah (distant migration beyond the borders of West Sumatra). In 1974-1975, 2 percent of the emigré population were found no more than $20 \mathrm{~km}$ away in the vicinity of a market town located through the narrow pass in the walls of the lake's caldera. They go there to work for a wage, usually in the rice fields, often on a seasonal basis when wage-labor opportunities are short at home, but sometimes on a long-term or even permanent basis also. Five percent were in the provincial capital, Padang, and 1 percent were in the nearby highland town of Bukittinggi. Eight percent were in the east coast oil town of Pakan Baru; 22 percent were distributed through seven other major centers in Sumatra; and 47 percent were in numerous small towns throughout Sumatra. Most of these smaller towns are satellites of the larger

\footnotetext{
7 See Dasril Abunain, "Monography Kenegarian II Koto, Ketjematan Tanjung Raya" (Bachelor's thesis, Andalas University, Padang, 1970) pp. 9 ff.

8 Chadwick, "Marantau," pp. $26 \mathrm{ff}$.

${ }^{9}$ Widjojo Nitisastro, Population Trends in Indonesia (Ithaca, N.Y.: Cornell University Press, 1970) pp. $249 \mathrm{ff}$.

${ }^{10} \mathrm{My}$ first visit to Koto Anu coincided with the need of the nagari administration to undertake a census for the provincial government. I undertook the census but expanded its aims to enumerate uniquely not only the population of the nagari but also the population that had originated from the nagari and could still, conceivably, mobilize some claim to residence there. My census was accompanied by, and indeed based on, exhaustive genealogical inquiry into the matriline.

This genealogically based definition of the Koto Anu population is of some interest because in attempting to arrive at a definition of the population that would both avoid including individuals who might also be included in similar enumerations of Minangkabau populations (i.e., which would arrive at an enumeration of a conceptually discrete segment of the Minangkabau population) and yet would succeed in netting all those with a mobilizable link with the nagari, I had first to define and use a definition of the residence structure of the households. This definition resulted from preliminary consultations with my main helpers and informants. At every household I asked, "Which female members of the matrilineage would stay in this house if they returned to Koto Anu, and of the remainder, where would they stay?" Considerable pains were taken to ensure that the reputed village residence of emigrants was not duplicated. In retrospect, this was scarcely necessary because few instances of equivocal residential affiliation were encountered. I asked unmarried male members of the matrilineage the corresponding question. I asked married male members of the matrilineage, "Did you marry a Koto Anu woman?" Men who had married Koto Anu women would be included in the household affiliation of their wives because residence is uxorilocal. Men who had married outsiders were not included in the survey at all. On the other hand, outside men who had married Koto Anu women were included. It was hoped that the exclusion of the former would compensate for the inclusion of the latter. In retrospect, as informants had forewarned, such an assumption was justified. Men who have married outside women never return with their wives, for there would be nowhere for them to stay, and unless they are divorced, they never stay more than a week or so if they return alone. Outside men who had married Koto Anu women, on the other hand, often come to the nagari with their wives and stay in their wives' residences and, indeed, may settle in the nagari.

Lineages that had been completely depleted through migration (the so-called pindah or moved lines) do not figure in the census unless they still had houses and/or land in the nagari. The number of moved lineages that had left without trace simply cannot be estimated. It is only in this respect, irrevocably moved lines, that the census did not reflect the extent of the total population originating from Koto Anu.
} 
centers, and some of them are actually in West Sumatra itself; only 2 percent of the emigré population were in Java at that time.

Because of the serial nature of Minangkabau migration, Koto Anu, like every other Minangkabau nagari, has established a unique distribution pattern of its emigrés in the rantau. The census forms and the associated genealogical interview give a strong impression of the orderly dispersal of emigrants. The most certain statement one can make is that if an unmarried girl migrates independently of her parents, it is to follow or accompany (both $i k u i k$ in Minangkabau) an elder married sister. Such a movement may follow within one year of the elder sister's marriage if the younger sister is already in late adolescence, and it has consequences for her later marriage and residence. It often means that a marriage will be arranged for her with a man who has migrated to the same destination and established himself there: and it follows that there is a strong association between the residence of sets of sisters in rantau. ${ }^{11}$ The initial destination of a young man is more strongly determined by perceived opportunity. It is also determined by where his kin are, but the kin in question may be his elder siblings or matrilateral cousins, a matrilateral senior kins-person, or a member of his bako (the father's matrilineage). Young men are particularly prone to early secondary and tertiary movements, again in response to perceived economic opportunity. Older people may also migrate to join their married children. Children migrate most often, it is said, to "follow mother" (although they often go with both parents). The localized networks of kin in the rantau have a strongly matrilateral color. Even when sets of sisters are separated through migration (having "followed" their husbands to their chosen destinations), there is often a secondary movement of one or more of them from a less-favored destination, which reunites them. Consequently, male members of a group of matrikin are relatively more dispersed over the rantau than are female members, as indeed they would have been on a tiny scale within the nagari, village principles of social organization thus reasserting themselves abroad.

\section{Genealogical Process, Devolution of Land, and Migration}

Migration is linked to the cultural core, the production of the food staple, to the devolution of land, and inevitably to genealogical structures and genealogical dynamics. ${ }^{12}$

\footnotetext{
11 I believe I am the first writer to have noted the extent of matrilineal asymmetry in the rantau but because all my research has been village based, the reader should note that it is not certain to what extent this is a characteristic of households, as opposed to choice of migratory destination. Naim, Merantau, p. 186, notes the extended nature of households in the rantau, but he does not particularly mention whether they are extended in a matri- or patrilateral sense. He says: "Another deviation is the co-emigration of wives and children to the rantau. In the prewar years, though married, many emigrants left their wives and children behind in the village. They return once a year or more, usually around the fasting month. ... The altruistic side of family life is also to be seen in the presence of other family members in the same house, such as siblings, nephews and nieces, cousins, parents, and sometimes other relatives from both sides" (my translation). The question is Whose parents or parents-inlaw (and whose siblings, nephews, and nieces, etc.)? Parents-in-law in Naim's table are ten times more common in the somewhat extended household in the rantau than parents. Because the respondents are all men, it is ten times more likely for the parents of the wife than the parents of the husband to be present in households in the rantau.

12 The customary law of inheritance in Minangkabau has received detailed attention in F. von Benda-Beckman, Property in Social Continuity (The Hague: Nijhoff, 1979). This topic is necessarily treated in a cursory fashion in the article presented here, where principally the usual course of succession to property (and not with anomalous or contested examples of inheritance) is dealt with to highlight the relevance for rural-urban migration of the succession to tenure cycle.
} 


\section{Genealogical Structures}

Although the Minangkabau kinship system produces a segmentary clan, subclan, and lineage structure, the system of personal address and reference militates against the cultivation of genealogical knowledge. Only the minimum genealogical knowledge that is needed to ensure the orderly devolution of land is cultivated, and it is encoded in relatively impersonal terms.

\section{The Genealogical Isolate}

Genealogical inquiry of any depth is delicate and, in polite contexts, even taboo in Koto Anu. ${ }^{13}$ Genealogical reticence leads to genealogical amnesia, and reticence and amnesia are facilitated by a complex system of address and reference whereby personal names and even the first person singular and second person pronouns are elided from conversation wherever possible in polite contexts.

To introduce a sociological theme at this point might seem digressive, but certain linguistic practices associated with personal address and reference in Koto Anu play a role that is both functional and infrastructural for the system of tenure and inheritance and ultimately for migration.

When attempting to plumb the limits of genealogical reticence and amnesia, the anthropologist isolates an entity with little ideological reality for the native, which I will call "the matrilineal genealogical isolate." But it is a naturally occurring entity bounded precisely by reticence and amnesia, and over generations, by reticence turning into amnesia. The boundaries of the isolate may differ slightly for different egos, so from ego's point of view it is an egocentric concept because degrees of participation differ in the exchange of genealogical information. The isolate identified by the research act is particularly narrow because of the polite context of the anthropologist's inquiries. But this artifact of the research act has a reliability that the egocentric view does not have because the researcher gets information from a number of sources within the isolate, especially if this is done during a household survey.

During a survey of four hundred houses, cross-information about the boundaries of the genealogical isolate, without collusion between informants, repeatedly convinced me of its sociological reality. A household survey of this kind is a peculiar intrusion that only an anthropologist from another country could get away with; Minangkabau researchers might have been aware right from the start of the delicacy of genealogical inquiry from their implicit knowledge of the system of address and reference. ${ }^{14}$

13 This situation is very different for the northern neighbors of the Minangkabau, the patrilineal Batak, for whom the exchange of genealogical information of up to twenty-six generations is a common mode of initiating and maintaining a conversation. See E. M. Bruner, "Medan: The Role of Kinship in an Indonesian City," in Pacific Port Towns and Cities ed. A. Spoehr (Tenth Pacific Science Congress, Honolulu, 1961), pp. 1-12.

${ }^{14}$ The full significance of name avoidance for the inheritance and tenure of land came to light in the course of an attempt to survey the lands and domestic economies of subclans in Koto Anu. I abandoned the survey when I realized that it was creating ill-will and apprehension, and I instead completed the survey of the two subclans where I was most well-known. Just as this project was nearly complete, word came to me that members of another subclan had reached consensus that they should not cite the names of ancestresses above their grandmothers in the concurrent genealogically based census. I feel that this was one indication of resistance to my inquiries into land-tenure rather than to the census itself. I suggest that people may have felt that extensive genealogical revelations put me in possession of potentially disruptive information.

At least one person seemed to be under the impression that I had some special expertise in eliciting genealogical information. A subclan headman asked me to record the genealogy of a man who was regarded as urang pupuih (from a genealogically depleted and matrilineally defunct line). He possessed considerable wet-rice 


\section{Personal Address and Reference}

Except to and among children and unmarried people, the use of a personal name for address and to a lesser extent for reference is considered impolite. Instead, a range of kin terms (father, elder sibling, etc.), a range of functional terms (teacher, various terms of address for chiefs, etc.), or, in the case of married men, titles, must be used. (Every man upon marriage receives a title such as Sutan Alam [King of the World], Sutan Rajo Ameh [the Golden King], and so on. In addition, certain pronouns are avoided: the terms aden (I), ang (thou masculine), and kau (thou feminine) are considered suitable only for use to and among children, among intimate adolescents, among adult peers in informal contexts, and sometimes in other very intimate and private contexts. They are also used in moments of extreme anger, when they are considered vulgar. Instead of aden the word $(h) a m b o$ may be used for "I/me." This word is cognate with the Malay term hamba (your servant) and is considered polite and deferential. There is no polite form of second person pronoun. When the second person is addressed politely, a noun-phrase (kin term, functional term, or title) is used as a substitute for the pronoun. A friendly way of addressing the second person is to use the term awak (we-inclusive). Confusingly, awak may also be used for first person singular reference as a polite substitute for kami (we-exclusive), and even for third person reference. In these cases, syntagmatic or contextual information is necessary to disambiguate the utterance. The extreme ambiguity of the term awak can cause confusion even for native speakers. The term kami (we-exclusive) may be used for "I/me" but not without ambiguity. Reference to singular first person possession is avoided when the addressed person may be said to have some potential claim on the property in question or just to encourage an atmosphere of friendliness and intimacy. The term awak may be used here, or reference to possession may be elided from the sentence altogether.

Syntactic strategies to avoid first and second person reference include oblique and cryptic syntax, such as passive construction and elision of the subject, and avoidance of imperatives.

To clarify third person reference, while still avoiding the direct use of names, various forms of mediated reference may be used of which teknonymy is only one form: one refers to third persons by stating each relationship to an individual who can be named with im-

fields, had no inheritors, and was thus in a position to sell his land outright; the other members of the subclan, hoping to bring a lateral claim into play to at least prevent him from selling, would have liked to establish some kind of tie to him. I was called in to clarify the situation. The best I could do, of course, was to formalize in black and white what was already clearly known, but it may have been believed that I had access to the subversive information (and proof) that they were after. Although in general it would be true to say that genealogical knowledge is rather private, the acute genealogical "amnesia" of the urang pupuih may demonstrate that in certain cases it is quite secret but can, ironically, become a matter for public concern.

I doggedly pursued the collection of genealogies in spite of its sensitivity; at one stage, I was confronted with a written genealogy that related people who until then had been considered discrete groups. However, no one could relate the contents of this genealogy from memory. Throughout I felt that I was treading a minefield of repression but had to continue the pursuit of themes indicated in my research proposal because the Indonesian government had issued a research permit that limited research to those themes. Despite the intense attention devoted to Minangkabau by anthropologists, the ethnography of land use, land tenure, and land inheritance floats in a detachedly legalistic way over these phenomena. I feel that owing to the taboo toward inquiry into these topics, researchers have consciously or unconsciously avoided probing too minutely and, indeed, have probably been gently steered away from detailed enquiry by their informants. It is true that certain individuals will freely discuss matters of inheritance in general and hypothetical terms. In fact, there is a considerable lore on inheritance. But the discourse of customary law experts is a wildfire of metaphor; and although it is grounded in a concrete knowledge of inheritance practices, it can seem obscure to the foreigner because reference to actual cases is edited from conversation. 
punity or who can be identified by means of an unambiguous positional or functional term or who can be identified diectically. The latter practice of mediated reference is the main means by which one can politely, if somewhat tortuously, conduct a genealogical interview; but with sufficient rapport and delicacy some of the norms I have described can be violated. Mediated reference may actually work to keep a certain shallow depth of genealogical knowledge alive, but it is frustrated in this respect by the most important of these practices (from the point of view of genealogical amnesia), namely, the taboo on pronouncing the name of a dead person. The other practices are important from the point of view of genealogical amnesia in that they sustain the last-mentioned taboo and are its sine qua non.

Finally, the nonnative anthropologist, as both a distinguished visitor and a notorious cultural naif, can violate many of these taboos, especially in the early stages of his fieldwork, without the full force of social sanctions being brought to bear on his behavior.

\section{The Per Stirpes Rule}

Even though it is difficult to talk about relationships in a precise way in a polite conversation, it is not impossible, and there is a precise genealogical idiom that may be used for talking about matrilineal relationships when the names of relevant ancestresses have been forgotten or when there is reticence concerning the names of dead people. Briefly, this idiom consists of referring to people who are related by having the same grandmother as dunsanak sa-anduang (close relatives with the same grandmother). By the same token, people related through MMM are dunsanak sa-uci (close relatives with the same great-grandmother), and those related through a more remote ancestress are dunsanak sa-iniyek (close relatives with a common remote ancestress). The expression dunsanak sa-uaik (close relatives with the same mother) sounds odd and would only be used to disambiguate the term dunsanak when it occurred alone. This idiom enables people to talk about land-sharing relationships in terms that encode the most important principle of inheritance-the per stirpes rule, which says that land that a woman has held must be distributed equally among her daughters. And thus this genealogical idiom works to encode and ultimately justify what may be a lessthan-uniform distribution of land within the landholding corporation, or commune. This idiom is an important representation for organizing the orderly rotation of lineage lands when not everybody has equal rights to land.

\section{How the Per Stirpes Rule Works in Theory}

How this kind of discourse works and how it organizes the rotation of lineage lands when not everybody has equal rights to land may be illustrated by reference to figure 2, a purely hypothetical example. In figure 2, although persons $A, B, C, D$, and $E$ are of common descent, they do not share equally in the total of land held in the landholding corporation. Suppose that long ago the ancestress iniyek at the top of the diagram had in her unique possession a certain amount of land. Today her descendants do not share equally in that land as they are differently related to her. $E$ will have a half-share in the land, and $A, B, C$, and $D$ together use the other half-share. $A, B, C$, and $D$ will account for this by saying that they together are dunsanak sa-iniyek (or just sa-iniyek) with $E$. This second half-share will be divided not into four for the four other participants but into three because three lines descend from the $u c i$ to the left: $C$ and $D$ will each get one-third share, the other third share being divided into two for $A$ and $B$. This division will be explained by saying that $A$ and $B$ are sa-anduang (of one grandmother), whereas they are together sa-uci (of one great-grandmother) with $C$ and $D$. 


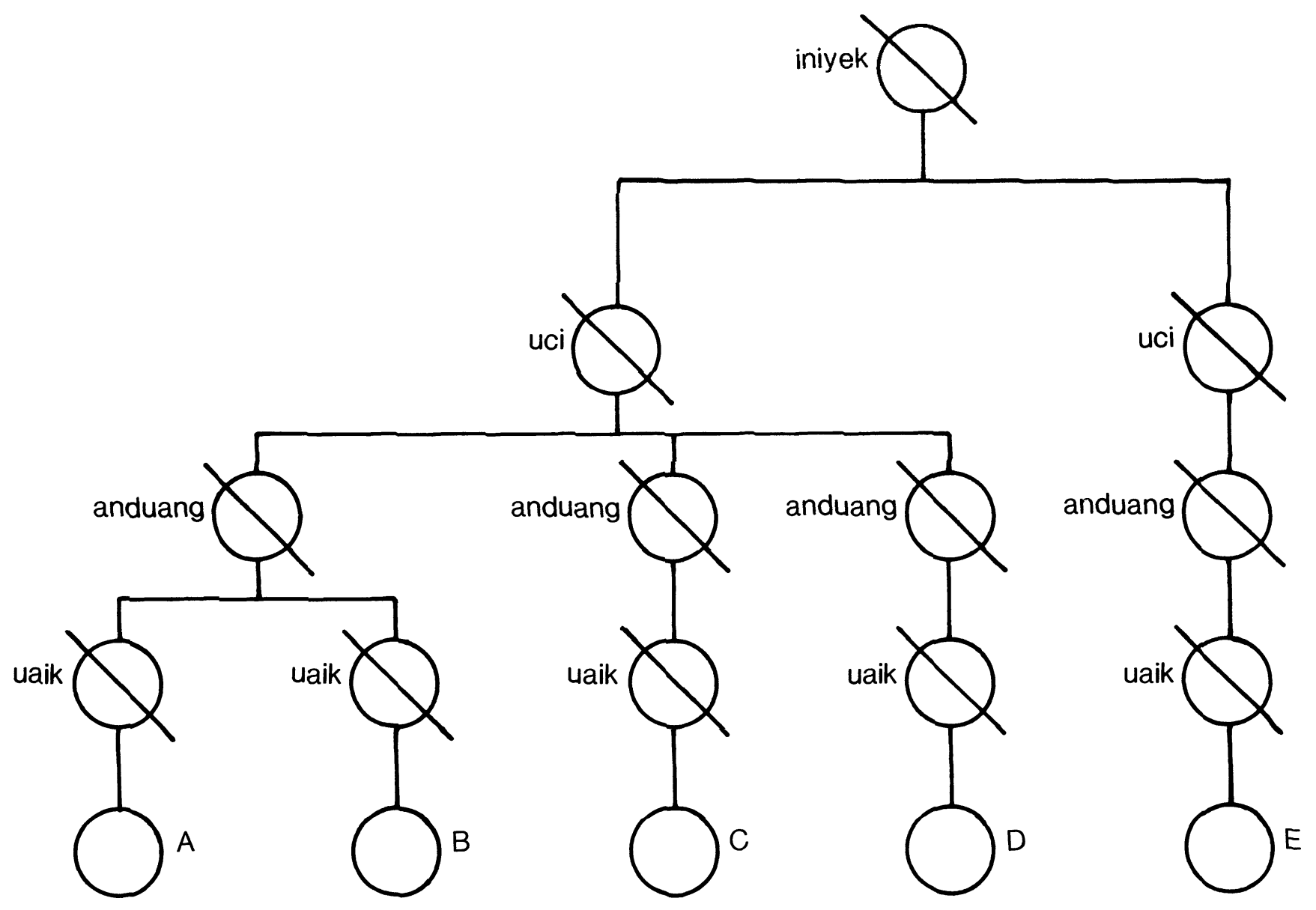

Fig. 2. THE PER STIRPES RULE OF MATRILINEAL INHERITANCE 
Suppose now that the uci of the figure had independently acquired some land through purchase. This land would today be shared but not equally among $A, B, C$, and $D$ according to the same per stirpes rule, but $E$, because she has only a lateral connection with the ancestress, will not be a party to the sharing of that land. In the same way, the anduang to the extreme left of the figure could have acquired land during her lifetime that today would be shared equally between $A$ and $B$ to the exclusion of $C, D$, and $E$ who do not have a lineal connection with the origin of the wealth. Note that the simple per stirpes rule that daughters divide equally the share in lineage land that they inherit from their mother ensures that those situated in the most fecund areas of the genealogy are the least favored in inheritance.

Although the matrilineal geneological isolate identified by the anthropologist is the lineage, the group of dunsanak identified by native speakers-the group among whom inherited land rotates, which may be less extensive than the genealogical isolate-is the landholding corporation. The landholding corporation is referred to as sa-buah paruik (one womb). The constituents of the landholding corporation are small domestic units referred to as urang sa-pariuak (the people of one rice-cooking pot). This domestic group, of which there may be more than one to a household, is associated with an undivided, determinate, and unequal share in the corporation's land and/or with some other source of income such as a salaried job, a trade, or wage labor.

\section{How the Per Stirpes Rule Works in Practice}

Within the landholding corporation (sa-buah paruik), the usually fragmented and scattered rice fields of the corporation are rotated among the parties to its inheritance. Rotation addresses the difficulty of dividing land equitably in any one year owing to the different sizes of plots, varying fertility, and other factors, such as availability of water and proximity to the homestead.

As can be imagined, the manner of rotation of a corporation's land can become confusingly complex over time and can easily become a matter for dispute. A senior male from each corporation is chosen as the manager of the rotation (tunganai or tungganai). His role is essentially that of a conciliator or communicator rather than an arbitrator, for the real power over land remains with the constituent landholders of the corporation who are usually women.

How then do these principles work in practice when men may come to inherit, when not everyone chooses to stay in the village and farm the land, and when women who are widowed do not preside over a domestic unit of their own? In figure 3, a diagram of an actual genealogy established through reference to land-sharing relationships, letters represent named individuals, dotted lines represent reconstructed pathways in the kin network. In this lineage there are seven pieces of sawah (wet-rice fields) of varying sizes and productivity. The manner of their rotation will be outlined one by one.

First, one large piece of sawah rotates among $A$ and the sisters $B, C$, and $D$, on the one hand, and the cousins $E, G$, and $H$, on the other. The manner of its rotation is as follows: this year, $A$ and $B$ have it; next year, $E$ and $H$ will farm it together; the year after that, $A$ again will have it, but this time together with $C$; the year after that, it will go to $G$ and $H$; the year after that, to $A$ and $D$; and finally, $E$ and $H$ will have it before the cycle starts over again.

A second piece of sawah is in the hands of $B$ alone; this sawah does not rotate although it is inherited property, but to compensate $C$ and $D$ for their lack of participation in its rotation, $C$ and $D$ have another, larger piece of sawah that rotates between them alone, to which $B$ never gets access. Although these latter two pieces of sawah are from the uci of $A, B, C$, 


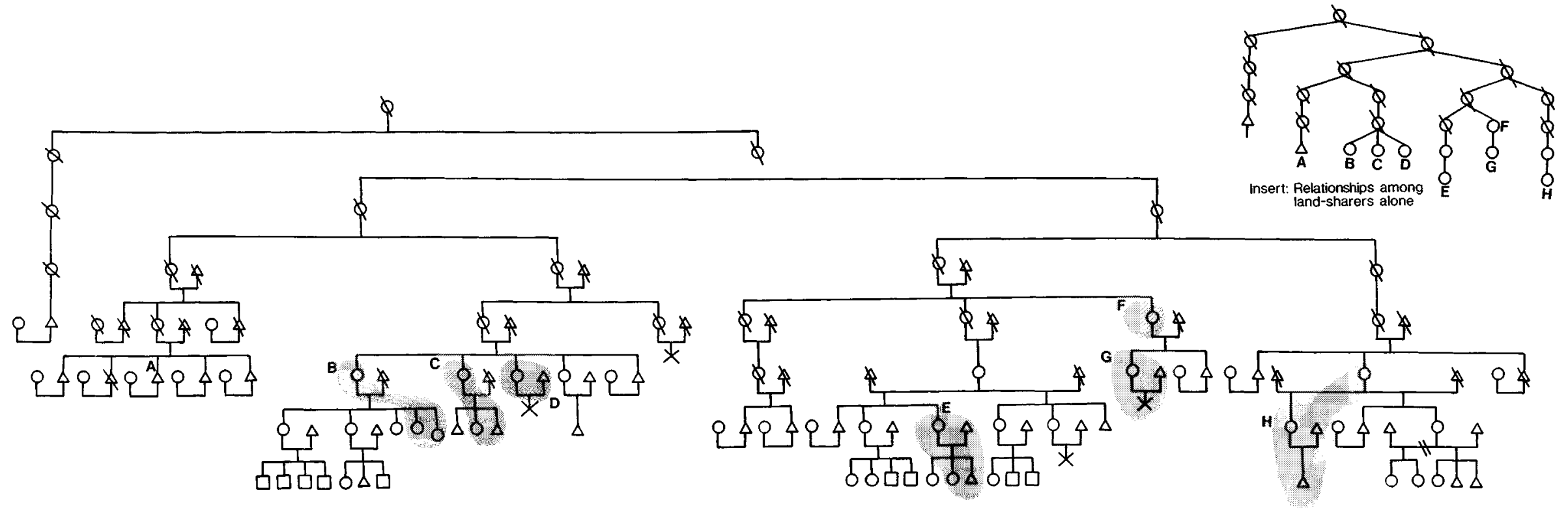

\section{Fig. 3. SA-BUAH PARUIK (A LAND-HOLDING GROUP)}

This diagram shows members of the matriline and their spouses only. Putative relationships are indicated with a dotted line. The eight shaded areas show domestic units resident in the nagari, matrilineage members not in shaded areas are resident in the rantau. Letters indicate individuals mentioned in the text with use rights in the corporations land. 
and $D, A$ does not share in the rotation; the reason given is that he is a man. That he shares at all in the rotation is owing to the fact that, although poor, he is a chief and needs a reasonable income to maintain the dignity of his office and as an inducement to stay on in the village and fulfill that role.

A fourth piece of sawah rotates among $E, G$, and $H$. $G$ has it this year, $E$ had it last year, and next year $H$ will have it for two years.

$F$ does not share in the rotation of these aforementioned pieces of sawah. She is an old woman who prefers to live on her own rather than join the household of one of her daughters. She has one small piece of sawah that is worked for her by neighbors and relatives. This land does not rotate. It is her compensation for being left out of the rotation of the other lands, and it will fall to $E, G$, and $H$ when she dies or decides to relinquish a claim on it.

Finally, two pieces of sawah were in the hands of $I$, of which one piece was sold and one pawned without consultation with the others. He considers himself to be from a depleted (pupuih) and, indeed, matrilineally defunct line and a genealogical isolate in his own right. But the others claimed that they could still remember when those two pieces of sawah rotated, how they rotated, and hence, their genealogical connection with him. They, therefore, privately disputed his right to sell, but it would have been too difficult and costly to fight the sale in court. The two necessary conditions for the land to have ended up in I's hands at all were first, that there were no female inheritors in the line, and second, that the land had ceased rotating for convenient calculation of the rotation. Any land, like this land, that is entailed in the female line should revert to lateral kin because a man cannot pass on entailed land to his children. However, it can be sold after certain options are exercised: it has to be offered first within the landholding corporation (sa buah paruik), second, within the subclan (payuang) and finally with the clan (suku). Traditionally, land may not be sold outside the nagari, but in fact, land has fallen to people in other nagari, through default mechanisms in pawning arrangements. Similarly, Koto Anu people own land in neighboring nagari owing to the same process.

Should any significant demographic changes occur in the above corporation, the rotation arrangement described would have to be partly or completely rethought.

\section{Principles of Land Inheritance}

In the example, from a lineage poor in land, it can be noted that people in the rantau do not share in the rotation of lineage lands. Working from a number of examples of this kind one can derive a hierarchy of principles, the first of which is the per stirpes rule and the remainder of which work to modify the per stirpes rule:

1. Any married woman is entitled to a share equivalent to her sister's share in land formerly held by her mother.

2. Widowed women are entitled to an independent share of the corporation's lands but not to the detriment of the household economies of their married daughters. In some cases, there is pressure on a widowed woman to relinquish her land to her prospective inheritors and to join one of their households.

3. A man is entitled to a share in the inherited lands but not to the detriment of his sisters, for a maximum period of his lifetime only (i.e., his children cannot inherit his share), and only if he is in need or is a chief and needs to live in a style appropriate to his office. Land held according to this practice is called sawah di-bao laki ka rumah anak-nyo (rice fields taken by the husband to his children's, i.e., his wife's house) or simply pam- 
bao-an (something carried away). The implication is that it will eventually return to women's tenure.

4. People in the rantau are entitled to a share but not to the detriment of those who choose to stay in the nagari.

A detrimental interest is one that reduces the general holding below a certain conventional subsistence level.

Although land is shared according to widely held principles, these principles are flexible given the consensus of all involved. These principles are ordered in importance, and those lowest in the order of importance tend to be discarded first when land is in short supply in the corporation.

\section{Address and Reference, and Genealogical Amnesia}

The only evidence for the nature of relationships within the corporation once names of ascendant kin have been forgotten (or suppressed) is the present or immediate past mode of rotation of land. Genealogical knowledge needs to be preserved in some form, for in cases of conflict the iron rule of per stirpes division is reasserted. The segmentation of landholding corporations is a traumatic and divisive event that occurs when genealogical (and affective) relationships have become remote, so once segmentation occurs it is best that people forget how the land once rotated. The sa-iniyek/sa-uci/sa-anduang terminology falls into disuse when no longer needed to calculate land rotation.

The taboos and restraint surrounding personal names and personal pronouns can, therefore, be seen as ultimately having an economic effect in facilitating the management of a certain mode of inheritance and tenure of land. This may not be the only function of the system of address and reference, but it does appear to be one of its functions. More precisely, by promoting and sustaining genealogical amnesia, the system of address and reference combined with the taboos on naming, especially the taboo on naming the dead, function to prevent the revitalization of old land claims (and old wounds) through reference to a principle of lateral inheritance when remote lines become depleted or matrilineally defunct (i.e., pupuih, see next)..$^{15}$

\section{Dynamics of Inheritance and Tenure of Land.}

The genealogical code plays a powerful role in determining the devolution of land. But it does not exist in a vacuum; it interacts with the codification of concepts of property, concepts of relative wealth, and concepts of the boundaries of the collectivity. The consequences for migration of the genealogical code can only be understood when these latter conceptualizations are also taken into account.

\section{Memorial and Immemorial Wealth}

Most land in Minangkabau is entailed in the female line. This does not mean that it cannot be sold or that it cannot be inherited by men. It means that a man cannot pass it on to his inheritors.

\footnotetext{
15 People from Koto Anu have recently told me that since my 1974-1975 fieldwork the taboo on naming the dead and, to a lesser extent, the other practices I have outlined are falling into disuse among the younger generation and among people long resident in the rantau. But I wonder whether this change may be an ongoing feature of Koto Anu linguistic practices: perhaps people only become serious about these practices when they have reached the age where they are deeply involved in the inheritance and tenure of land within the nagari and are thus aware of the potentially disruptive and scandalous nature of extensive genealogical revelations.
} 
The sale and pawning of land are fairly common occurrences. As mentioned, before land can be sold the traditional options on its purchase must be exercised. This stricture applies to harato pusako (traditional or ancestral wealth). Adat (customary law) experts recognize two subspecies of ancestral wealth: harato pusako tinggi (high ancestral wealth) and harato pusako randah (low ancestral wealth). Low ancestral wealth is that which was purchased by a known forebear (a known node in a genealogy) located only a few generations back. The ancestress in question, although her name may be rarely cited or even unknown, covers a number of descendants less extensive than the landholding corporation, and the land is distributed among them according to the per stirpes rule. High ancestral wealth, on the other hand, is property descending at least from the ancestress at the apex of the landholding corporation: in principle, all genealogical lines are party to its distribution although in unequal shares because of the per stirpes rule. Villagers more commonly talk in terms of sawah tuo (old rice fields) and sawah bali (bought rice fields), which are similar but more vague and flexible concepts. These distinctions between memorial and immemorial wealth are, in practice, fluid and negotiable in some intermediate cases (where they may become the crux of a dispute) precisely because of genealogical vagueness resulting from the forgetting and even suppression of the names of ascendant ancestresses.

A further category common to both legal experts and the populace is that of harato pancarian (earned wealth), which can be freely disposed of because it has not become subject to matrilineal entailment. In practice, entailment is something that happens insidiously because of a widespread sentiment that rice lands, whatever their origin, should properly be held by women. Thus even earned wealth, when it is in the form of houses or rice fields, is commonly inherited by the daughters of a marriage in Koto Anu. By the same principle it is destined in turn for their daughters, by which time, without doubt, it is at least low ancestral wealth and henceforth, matrilineally entailed according to immemorial custom. ${ }^{16}$

\section{Collectivism and Individualism}

It can be seen from the preceding discussion that assertions that the family property in Minangkabau is undivided 17 or even that Minangkabau practices a form of primitive communism ${ }^{18}$ are not precise. The members of the landholding corporation share their land, certainly, but they hold unequal and notionally divided shares. The corporateness and solidarity of the landholding corporation is apparent in the practice of land rotation and with regard to the traditional options on the sale of entailed land, but there is always an implicit and unequal division along individual lines.

Demographic changes within the lineage can sometimes alter the relative valency of shares during the life of the corporation. In view of this, the rotation of land in preference to its outright division could be seen as a way of keeping alive the network of those potential claims whose valency can alter at any time (e.g., with the death of a woman without daughters, when a principle of lateral inheritance comes into play owing to the matrilineal entail-

\footnotetext{
16 Any land, or other wealth, that is not matrilineally entailed may be inherited according to the proven wishes of a testator or, in default of a will or testament, according to the Koranic fractions. The simple rules set out in the Koran have a large range of applications, and textbooks are produced for Indonesian law students that give them many examples of how the rules are to be applied in actual cases. A typical handbook is H. Mahmud Yunus, Turutlah Hukum Warisan Dalam Islam (Jakarta: Al-Hidayah, 1974).

17 B. Schrieke, "The Causes and Effects of Communism on the West Coast of Sumatra," in B. Schrieke, Indonesian Sociological Studies, pt. 1 (The Hague: Van Hoeve, 1955) p. 140.

18 J. V. Maretin, "Disappearance of Matriclan Survivals in Minangkabau Family and Marriage Relations," Bijdragen tot de Taal-, Land-en Volkenkunde 117: 168-95.
} 
ment of ancestral wealth). The network of potential claims includes members of the corporation resident in the rantau and accounts for some of the emigrant's attachment to his or her natal community. Many absent people in my survey were said to return periodically to "look at the house" or to "look at the rice fields" to renew their claims on the ancestral wealth, it may seem, and to reassert their implicit participation in a fluctuating and immanent division of that wealth. The donation of the full or partial seo (rent) of the foregone share of the family fields to the visiting emigrant is the reciprocal gesture by the village stayat-home.

If there is consensus within the corporation, an explicit division can be made associating each of the constituent lines with concrete plots of land, thus segmenting the corporation, even if it involves monetary compensations and even if it means building dikes through some of the plots to arrive at an equitable division. This is an embarrassing thing to have to do, and division is avoided while real or putative relationships are still close. But its finality is ensured by the action of the taboo on naming dead people, which occurs in the context of restraint from direct personal reference in polite discourse.

Thus a tension between individualism and collectivism is written into the cultural practices associated with Koto Anu's core subsistence adaptation, the production of rice.

\section{Defunct Lines and Lines That Have Flourished}

The recognition that fecund areas of the lineage are penalized for their fecundity is encoded in the popular distinction between urang pupuih (a people who have become depleted and nearly defunct) and urang kambang (a people who have blossomed or developed numerically). The position of corporations that have become matrilineally defunct (pupuih) is notorious. They may consist of one genealogically isolated person, sometimes, scandalously, a $\operatorname{man} .19$

More often, urang pupuih consist of a small number of people who, because it is easy for a small number to reach consensus, have a propensity to sell their land to finance ventures in the rantau, and who, thereby, often quit the nagari altogether. Matrilineally "developed" (i.e., kambang) lines are prone to migration for the same reason, poverty, but because of a different genealogical and economic dynamic. In their cases, the disposal of any of the corporation's land is difficult because of the difficulty of reaching consensus among so many interested parties. Often, a few representatives are left behind, caretaking a pathetic and fragmented holding that is impossible to dispose of. ${ }^{20}$

\footnotetext{
${ }^{19}$ The position of urang pupuih consisting of a daughterless woman or women is not so scandalous, for adoption of a sister's or matricousin's daughter(s) may solve the problem of inheritance within the corporation or within the same subclan. Properly adopted daughters have full inheritance rights.

20 The very different dynamics of matrilineally "defunct" lines and matrilineally "developed" lines is the solution to a paradox proposed by Schrieke. For Schrieke it was the "family" and the "primitive communism" that was supposed to prevail within it that facilitated migration among the Minangkabau.

The current matriarchal system, based on undivided family property, has opened up the possibility for the surplus male population, which is no longer able to make a sufficient living from farming owing to lack of land in its own region, to find work elsewhere. And so we find that in many areas the men leave their native villages when the rice has been planted to earn the money which their own region cannot supply in foreign parts, where they stay until harvest time. When opportunities are plentiful for such emigrants, as in 1925 when in Jambi and Kuantan rubber seemed to promise gold and in many places as much as twenty five per cent of the male population left home, it may even happen that crops are endangered by a shortage of hands to attend them. But such conditions are exceptional. Nevertheless such temporary emigration is quite the rule in many regions. Emigration often becomes more or less permanent, too, particularly in the case of
} 
The complete disposal of the corporation's land, when it happens, is often a gradual process whereby land falls to others by default in a pledging (gadai) arrangement. Poverty initiates attrition of lineage lands in small corporations, and once the process starts, it is almost inexorable. When the process is complete, the corporation no longer has any rationale for its attachment to the nagari; and where previously its members were said to have gone marantau (to have emigrated, in the uniquely Minangkabau sense), they are now said to have pindah (to have "moved," with the implication that they will never return). Because ownership of land and houses is the only durable memento of a corporation's presence in the village, my census only captured the "moved" (pindah) lines who still had some tenuous tie with the nagari or who had left some stigmata of their former presence. Owing to the interplay of demography, inheritance, and the market in land, unknown numbers of people from Koto Anu have vanished into the rantau, and for that reason it is not possible to estimate the scale of emigration with complete accuracy.

The pupuih/kambang (defunct/developed) distinction does not apply only to whole corporations but can also be used to describe the pattern of fecundity within the lineage. Even when the corporation as a whole is not overwhelmed by the pressure of numbers, and even where it does not profligately dispose of its land, the pattern of migration is still partly determined by the pattern of fecundity and sterility in its constituent lines. Whether or not one has a viable share of land (or can marry someone who has) is always an important factor in determining whether or not one will migrate.

\section{Original Settlers and Newcomers}

A further social distinction relating to the inheritance and tenure of land in Koto Anu is that between urang asa (original settlers) and urang datang (newcomers). The original settlers

small traders or of those who have, for instance, acquired land on the Malay peninsula or have found a means of livelihood abroad. But even then the tie with the land of the emigrant's birth is not by by any means entirely broken, thanks to his claim on the family property. If the self-exiled Minangkabau feels a longing to return home, he knows, in most cases, that he will not be obliged to face the problem of earning a living immediately, because, thanks to the family property, the family will supply him with food and clothes at least for a time. It is the family property, too, which has enabled many of the younger generation of the present day to make their way in the world, owing to the fact that from it more could be supplied to pay for their education or capital to start them in business. On the other hand the family profits from the earnings of the periodic, temporary emigrants, for the family also benefits from the earthly treasure collected by its members in foreign parts....

Here we find again the same clash of different tendencies in present-day society to which we called attention above. On the one hand there is the natural attachment to the joint family, which has by no means become entirely extinct, and on the other the individualizing action of trade and the modern currents of life into which even Minangkabau is being drawn-Minangkabau in the first place, one might almost say, because it was the traditional family property which has made emigration possible. Schrieke, "Causes and Effects of Communism," pp. 140-41.

The irony in Schrieke's analysis is that a shortage in the "family property" (land) makes emigration necessary, but the family property also makes it possible. The paradox is resolved when it is understood that shortage encourages the emigration of urang kambang but the second case is a matter of urang pupuih.

This analysis assumes that the conditions similar to those I have described for Koto Anu also prevailed generally in Minangkabau at the time of Schrieke's observations. Specifically, I am assuming that the darek was occupied more or less to capacity many years ago. The question lies not in the absolute ratio of arable land to population but in the marginal utility of land and land use compared to the return from forms of enterprise other than farming. That a good proportion of high-quality sawah (that mentioned in the body of this article) remains uncultivated in Koto Anu shows that the availability of land, and hence population pressure, are not in isolation factors that influence migration; migration occurs in a context in which opportunities within the nagari are weighed against opportunities in the rantau. 
are those lineages whose ancestors are said to have come directly from the slopes of the volcano Marapi some time after the founders of Minangkabau descended from that peak. The newcomers are those whose ancestors are said to have come later and attached themselves to patrons among the original settlers, and who were eventually adopted into one of the six Koto Anu clans.

This is a sensitive topic in Koto Anu. Every clan has lineages that are said to be "newcomers." In public, the issue is spoken about in vague and general terms, for no one likes to talk about it in a more specific way. However, in private the issue is kept alive by attributions of "newcomer" to specific families. No one will acknowledge that they themselves are newcomers. One wonders if the reputed newcomers are even aware that that is what they are supposed to be.

The newcomers are said to have come hundreds of years ago and attached themselves as clients to branches of established lines. It is said that one knows who the newcomers are by virtue of the manner of rotation of the most ancient ancestral property: specifically, the newcomers do not share in the rotation of the reputedly most ancient ancestral property of the lineage or subclan. It is not admitted that anomalies in the rotation may have come about in other ways (as, for instance, when particular fields cease to rotate for ease of calculating the rotation). My position, which is not shared by those with whom I have discussed this matter in Koto Anu, is that if one needs to attribute a cause for the poverty of putative kin, one need look no further than well-known, everyday processes, without asserting an extra, obscure mechanism for which there is only mythological evidence. It seems that there is here a degree of denial (in the psychoanalytic sense) that current institutions can result in poverty. ${ }^{21}$ When asked how it was known that the newcomers had arrived after most of the land in Koto Anu had already been claimed, when in fact the origins of all lineages in Koto Anu were lost in the mists of genealogical amnesia, I was taken aside by certain of the selfreputed "original settlers" who discreetly pointed out that the evidence is their poverty in land. This poverty in land is supposed to be an originary defect that they have never been able to overcome and is associated with backwardness in other areas, such as education and incentive.

\section{Datuak Basaluak Ameh and Datuak Batungkek Intan}

For an insight into the dynamics of discourse where the terms newcomer and original settler are used, it is useful to look closely at the two subclans that I came to know best and among whom I was able to study the distribution of land and the dynamics of its devolution in time.

The two subclans (payuang, or umbrellas) in question are the two segments of an original single subclan. The title of the chieftainship of the original clan was Datuak Pangulu Usali (literally, the Original Chief). And the unsegmented clan would have been known as

21 If my position is incorrect, then I look forward to further dialogue with Minangkabau people in order to resolve this disagreement. In Koto Anu, many people hold a compassionate attitude on this subject, and among them are some of the most influential figures in the nagari. It was pointed out in public discussions that this issue is best forgotten altogether because the distinction is odious and pointless. The word that frequently came up in these discussions was toleransi, which Poerwadarminta's dictionary (W. J. S. Poerwadarminta, Kamus Umum Bahasa Indonesia [Jakarta: Balai Pustaka, 1987]) equates with the Indonesian concept of tenggang(kan) (tanggang in Minangkabau), meaning "to have respect and sensitivity toward others" (see J. M. Echols and H. Shadily, An Indonesian-English Dictionary [Jakarta: Gramedia, 1985]). In circulating an article that discusses this issue explicitly, I feel that I may be violating a central Minangkabau value in order to discharge my responsibility as a scientist. I hope that I may be forgiven for following the latter course. 
Payuang Pangulu Usali (literally, the Umbrella of the Original Chief). The two modern segments are headed by chiefs with the titles, respectively, of Datuak Pangulu Usali nan Basaluak Ameh and Datuak Usali nan Batungkek Intan (i.e., the Original Chief with a Golden Turban and the Original Chief with a Diamond Sceptre). The two subclans are, therefore, referred to as the "umbrellas" of "Golden Turban" and "Diamond Sceptre" for short both among the populace of Koto Anu and in this article. (These are pseudonymous but verisimilar titles.)

The first Datuak Usali lived "many hundreds of years ago" and came with his brother and two sisters "directly from the foothills of the volcano Marapi" to pioneer land on the shores of the lake. The brother of Datuak Usali became the first katik (Indonesian-khatib, religious functionary) of the clan. His two sisters initiated the two matrilines that eventually segmented into the two present-day subclans.

At the time of the segmentation, in order to achieve an exactly equitable division of the rice lands, one small plot (ecek) of wet-rice land was divided by building a dike down the middle, forming two minute plots, one going to each of the new subclans. The fate of these two small plots of land has differed in each subclan. In the "Golden Turban" subclan, it still rotates today among all the lines of the subclan although it is of trivial economic importance. My informants explained that this is still done as a token of the solidarity and kinship of the whole subclan, thus constituting them as a corporate group (sa-buah paruik, or one womb) in a symbolic way at least. However, even those involved find the complex rotation of this plot mind-boggling, and it occurs over a period of many years. It is conceded that there is a level of compromise and simplification in the rotation. Indeed, its rotation can never be exact because of vagueness and uncertainty about the manner of genealogical relationship among the constituent "wombs" of the subclan. In the Diamond Sceptre subclan, however, the corresponding plot has ceased to rotate among the whole subclan and remains with a family who are said to be original settlers.

The members of Golden Turban are said to be, in general, ten times richer in land than the members of their sister Diamond Sceptre group. However, in Indonesia, because of unprofitable share-cropping arrangements, people with ten times the land of others are not necessarily ten times as rich. In Diamond Sceptre, most people are wage-takers working on the land of other people, including their kin in Golden Turban. Diamond Sceptre is not uniformly poor, and Golden Turban is not uniformly rich. The Diamond Sceptre group includes one immemorially "rich" lineage (the holders of the small nonrotating subdivision of the plot divided at the time of segmentation of the Original Chief subclan), and the Golden Turban group includes one recently destitute family who have, in the lifetime of their oldest members, disposed of all their land to finance quixotic petty trading ventures in the rantau. Although original settlers by known descent, they have fallen to become no better than newcomers.

All the constituent groups of the Golden Turban subclan are said to be original settlers. This includes the one recently impoverished family. Most of the Diamond Sceptre subclan are said to be newcomers, with the exception of the one "rich" family.

Because the people of the Diamond Sceptre subclan are so poor in land, they are forced to find their living in other ways. In fact, many of them supplement their livelihoods by working for a wage on the land of the relatively rich. The people of the Golden Turban subclan, on the other hand, are forced to employ wage laborers in their fields in order to cope with all the work. It is very natural for them to job out this work to the pool of disposable 
labor among their kin in the Diamond Sceptre group. Between the Golden Turban and Diamond Sceptre subclans the network of such interdependence is particularly densely connected. In fact, the lines of interdependence and solidarity between rich (Golden Turban) and poor (Diamond Sceptre) subclans are more marked, more multifarious, and obviously more substantial in economic terms than the network of solidary relationships within the impoverished subclan. This disparity is obvious even to the outsider who is able to observe visiting relationships and cooperation on ceremonial occasions. The failure of Diamond Sceptre's half-plot from the segmentation process to rotate among all its members is just as symbolic as the exhaustive rotation of Golden Turban's half-plot among its members, although it was never put to me in quite these terms.

\section{Our People}

In light of the above discussion, it is possible to see the whispered original settler/newcomer distinction as having an ideological function in discourse. Its function is to distance the rich from the poor in moral terms and to override certain other moral axioms in Koto Anu culture. In Koto Anu, as in other parts of Indonesia, an ideology of generalized kinship is very strong: the idiom kinship is extended with varying degrees of intensity to everyone with whom one is in a moral relationship, including foreign anthropologists. It is declared explicitly that all members of a subclan are to be treated as kin, even though a relationship cannot always be demonstrated. Less markedly, all members of a clan are kin; and this axiom is used to rationalize clan exogamy.

All of the people one comes into contact with are addressed as kin in some way ("father," "mother," "mother's brother," "elder sibling," etc.), and a common way of ingratiating oneself with a stranger at the market, say, is to address him or her as sanak (kinsperson, short for dunsanak). Thus there is a series of concentric circles of decreasing kinship.

One way of including someone within the range of significant kin is to refer to him or her as urang awak (one of our people). I encountered this term when people were talking about the various ambits of kinship within the landholding corporation with regard to land and in other contexts.

At its most extensive level, the expression urang awak is used to refer to one's fellow Minangkabau, whatever their local origins. Thus urang awak (our people) can simply mean "Minangkabau"; and this is how the national press sometimes refers to Minangkabau colloquially, although the use of the term by an outsider to refer to Minangkabau is obviously inappropriate in Minangkabau semantics.

The term urang awak can also be used negatively to exclude someone from the kinship circle. A person knowledgeable about relationship within the two subclans discussed in the previous section of this article (Golden Turban and Diamond Sceptre) explained that there were anomalies within the constitution of the two subclans; one lineage of Diamond Sceptre was actually more closely related to the members of Golden Turban. This happened to be the one lineage of the poorer subclan that was rich in land. Thus they were, and the remainder of the subclan was not, our people. The informant drew a little boolean diagram to make sure that the relationship was understood. His account was intended to show a consistent picture of all the supposed original settlers, such as himself, as related and of one solidary group, in fact if not in name, and to isolate conceptually all the supposed newcomers. It was his actions as much as anything else that alerted me to the ideological function of the original settler/newcomer terminology. Note that the attribution of newcomer could be true in 
the historical sense, although there is never any convincing evidence for this, and still fulfill the ideological function indicated.

Although I was not privy to the full wealth of detail by which the original settler/newcomer distinction is sustained, there was a great deal of rationalization that made this discourse seem very plausible. For instance, disputes in the Diamond Sceptre subclan concerning which line should gain the position of chief have been framed partly in terms of the original settler/newcomer distinction. And the fact that the Golden Turban subclan retains the title of katik (religious functionary), the Diamond Sceptre subclan having no religious leader of its own, is also justified in these terms.

However, to the foreign visitor the basic distinction involved here seems to be that between rich and poor-something distasteful to the intensely democratic and egalitarian Minangkabau. And the rationalization that the fundamental distinction of rich/poor is subject to, such as attributions of newcomer, seems to function as a conceptual bulwark against the flow of wealth that should normally occur among kin.

In Minangkabau, the discrepancy between rich and poor is felt as a conceptual anomaly by both rich and poor people, and it motivates a lot of their behavior. When Minangkabau are asked why they go marantau, the almost invariable answer is mancari (to seek a living), although their economic plight in the rantau is often far worse than it would have been in the nagari and even though they know that other ethnic groups who are poorer than Minangkabau (e.g., in Central Java) are not highly migratory.

In Minangkabau, people migrate because they are poor, certainly, but they do so above all to recuperate status that is felt to have been diminished at home, that is, in order to undo a conceptual anomaly in a world where ideally everyone is equal, where everyone is kin, and where sharing is expected.

\section{Collectivism, Individualism, and Migration}

The communal nature of Minangkabau land tenure is apparent in the rotation rather than partition of family lands: the individualism of the system is apparent in the fundamental per stirpes rule that places priority on the immediate mother-to-daughter tie. Indeed, the truth of Minangkabau inheritance is the per stirpes rule that governs the rotation of plots of land within the undivided holding of the sa-buah paruik. And it is the simple iron rule of per stirpes division that comes into force at the moment of segmentation, whatever the concessions that have been made before segmentation. Segmentation, when it occurs, must be absolute, and the system of personal address and reference, including the taboo on using personal names, plays a role in inhibiting the cultivation of genealogical knowledge and thus preventing the play of lateral claims and concessions from beyond the boundaries of the landholding corporation, even if this is not its primary function.

The way fecund lines are penalized for their fecundity plays a role in determining the choice to migrate of women in disadvantaged positions in the landholding corporation. ${ }^{22}$ And it generates a reality of differential wealth within the corporation, which does not sit well with the egalitarian ideology of generalized kinship in Minangkabau. The discomfort of disadvantaged shareholders and disadvantaged lines is as much cognitive as substantive. The advantaged also experience cognitive discomfort at the relative poverty of their close and distant kin and an ideology relating poverty to recent settlement in the community

22 Whether the factors operating on women in marantau also applied in earlier eras is something that can only be hypothesized here. For the purposes of argument it is assumed that the way in which the cycle of succession to 
serves to modify the basic egalitarian ethos, distancing the "rich" from the kin who are often wage-takers in the agricultural activities of the "rich."

Matriliny, Migration, and Minangkabau

The migratory tendencies of the Minangkabau are often related to their matrilineal social organization at home, not least by the Minangkabau themselves. Folk theories should not be taken at their face value. They must be partly correct to stand up to experience, but they may not be the whole truth.

\section{Folk and Scholarly Theories}

The view proposed here is that scholarly theories of the matrilineal causation of migration are retranscriptions of folk theories and involve the same omissions as the folk theories.

The various arguments that men's marginal position in Minangkabau society is related to their migratory propensities differ only in the strength that they attribute to this factor. For some authors (and for many Minangkabau people) matrilineal social organization is seen as being so uncomfortable and inhospitable for men that it virtually forces them to migrate. Other authors state merely that the marginality of men facilitates but does not necessarily force their migration. ${ }^{23}$

This widespread consensus is neatly illustrated by the views of Mochtar Naim who is the leading scholar of Minangkabau migration:

In this matrilineal descent system, the father is not a member of his children's descent-

line. $\mathrm{He}$ is regarded as and is treated as a guest within the family, his main aim being the furthering of the descent line. His is called samando or urang sumando. His proper place is in the descent-line of his mother where he functions as a male family member. Traditionally, in any case, his responsibilities were there. He was a representative of his descent-line and a protector of the wealth of the descent-line; at the same time he had to refrain from making use of the products of his family lands because he had no right to any part of them for himself. Moreover, he was not given any space of his own at his parents' (matrilineal) house because all the rooms were provided for female members of the family, in order for them to receive husbands at night. The shaky position of men is a

tenure of land influences decisions to migrate has a wider contemporary and historical application.

23 Zahara Daulay, "Minangkabau: A Preliminary Study of the Culture and People" (Master's thesis, Cornell University, 1960), suggests that the mobility of males is "made possible" because of the matrilineal kinship arrangements. This is the causally weakest version of the theory. The marginal position of the unmarried male in the household of his parents, the marginal position he occupies with regard to his wife's economic activities when he is married, and his uncertain residential status as a youth and for some time after marriage, all facilitate an early independence and continuing exposure to extrafamilial influences. T. Kato, (Matriliny and Migration, p. 116), shares this view of Minangkabau social organization as a facilitator of migration among Minangkabau men. Other writers posit a stronger form of causation: matriliny is positively stressful for men, and migration is a response to this stress. Swift considers that the main factor that induces Minangkabau men to go marantau is the pressure that arises from being a man in a matrilineal society. See M. Swift, "Minangkabau and Modernization," in Anthropology in Oceania: Essays presented to Ian Hogbin, ed. L. R. Hiatt and C. Jayawardena (Sydney: Angus and Robertson, 1971) 258-63. Swift's views are supported by the work of a psychiatrist in Jakarta's general hospital that relates mental illnesses manifested by young Minangkabau men in Jakarta to socio-organizational factors in the homeland. See I. G. Mitchell, "The Sociocultural Environment and Mental Disturbance: Three Minangkabau Case Histories," Indonesia 7 (April 1969): 123-37; idem, "Points of Stress in Minangakbau Social Life," Review of Indonesian and Malaysian Affairs 6 (1972) 96-150. 
crucial characteristic as we shall see further when we speak of the social motivation behind merantau....

Marriage, because of these things, does not create a new nuclear family, because husband and wife each remain members of their own descent-group. Because of this the nuclear family understood as consisting of mother, father and children as a unit is not to be found in Minangkabau social structure because it is always overshadowed by the matrilineal descent-line system which is much stronger than it. As a consequence, children are counted as members of the mother's descent-line and are closer to the mother and other members of the descent-line. The weak tie with the father is even more clearly seen when the male has married polygamously, and visits his wives in turn, and meets his children more rarely. This tie becomes even weaker when divorce occurs, such that he rarely ever meets his children. ${ }^{24}$

In the relevant following chapter ${ }^{25}$ Naim develops this statement further and expands on the difficulties facing the urang sumando (in-marrying male) and the conflict of loyalties between his wife's house and his parental house and finally concludes that these matrilineal and uxorilocal social arrangements are the main motivation for marantau and the single factor that distinguishes Minangkabau migration from the migration of other ethnic groups in the Indonesian Archipelago.

My argument is with the way folk complaints have been uncritically accepted, with the exceptionless way the description is formulated, and with the omission of any discussion of pressures to migrate acting upon women.

\section{Appeal to Particular and General Theories of Matriliny}

The widely shared view that there is a relationship between the marginality of men in Minangkabau and their migratory tendencies may be referred to as the "particular theory" of matriliny in this case. It is not incorrect but merely incomplete. It probably has its origins in the insistence of the various scholars' Minangkabau informants, and it may seem that these writers can take heart from a general theory of matriliny. Whether or not the general theory is correct is not at issue here, except that in my view, aspects of the Minangkabau case constitute a counterexample to the general theory and effectively falsify its universality, thereby considerably weakening any appeal to general theory by proponents of the particular theory.

\section{The General Theory of Matriliny}

The general theory of matriliny also sees this form of social organization as facilitating the peripherality of men, releasing them for activities at the margin of society, but it is more positive about the position of women in this process, adopting a frankly functionalist view of the interdetermination of men's peripherality and women's centrality. ${ }^{26}$

\footnotetext{
${ }^{24}$ Naim, Merantau, pp. 19-21.

25 Ibid., chap. 6: p. 6.

26 It has long been noted that matrilocality, at least, appears where women's contributions to subsistence are substantial and especially where feminine solidarity in work groups is important for production, processing, and distribution of basic foodstuffs. See M. W. Helms, "Matrilocality, Social Solidarity, and Culture Contact: Three Case Histories," Southwestern Journal of Anthropology 26: 197-212. This correlation still holds where women's economic contribution is substantially supplemented by the hunting and fishing activities of men. See K. Gough, "Variation in Residence," in Matrilineal Kinship, ed. D. M. Schneider and K. Gough (Berkley: University of California Press). A more specific and critical factor is the "relatively greater importance of female work-sites over
} 


\section{A Counterexample to the General Theory}

However, the account I have given of land inheritance and tenure practices in Koto Anu provides grounds for supposing that in Minangkabau not only is male migration facilitated by the nature of social organization at home but also there are pressures on disadvantaged landholders (who are usually women) that might strongly induce them to want to migrate, thus providing a counterexample to the general theory while deeply questioning the particular view. This line of argument will be taken up again, but in the next few paragraphs some objections are raised to the orthodox view of Minangkabau social organization and to the particular theory relating social organization to migration.

\section{Objections to the Orthodox View of Minang Social Structure}

My main objections to the views of the writers cited who hold with the particular theory of Minangkabau matriliny, concern their failure to refer to a completely contemporary situation and to the exceptionless manner of the theory's formulation.

\section{Differences between the Particular and General Theories}

Before an examination of the ethnography it is also necessary to clarify the relationship between the particular theory of Minangkabau matriliny and the general theory of matriliny. The particular theory states that in Minangkabau, because the male is peripheral to the domestic economy and loosely attached to it, he is easily spun out of the system to its boundaries; it is a theory of men's peripherality. The general theory states that because of the centrality and functional importance of women's economic role in certain societies, they support a matrilocal (and often matrilineal) form of social organization and is, thus, a theory of women's centrality. In the following pages I will argue from ethnographic observation that the particular theory is badly argued and is based on a descriptively inaccurate view of men's and women's roles in Minangkabau. In certain respects, Minangkabau constitutes a counterexample to the general theory, and in fact, matriliny constitutes a centrifugal force for some women in Minangkabau; that is, certain features of matrilineal inheritance and women's ownership of land act to induce women in disadvantaged positions to migrate.

\section{Ethnographic Considerations}

My own ethnography led me to wonder about the precision of descriptions of Minangkabau social organization, and therefore, about their suitability for theory building or testing.

those of men" (Gough, p. 553). Matrilocality may be characteristic of societies "in which women's work, of whatever kind, is done in or near the home, while men's pursuits periodically take them far from home" (Gough, p. 556). The peripatetic male is a common although by no means invariable feature of matrilocal societies, the relationship having something to do with the fact that "while men are away, engaged in hunting, warfare or raiding, trade or migrant labour, it is no doubt 'congenial' for women to reside uxorilocally rather than with affines" (Helms, "Matrilocality," p. 197).

Helms takes up Gough's line of argument to show that for three Amerindian societies the "adaptive significance" of matrilocality was a response to the peripatetic nature of men's activities, combined with a sedentary adaptation in women's activities. "It is suggested that the functional value of cores of consanguineally related women lay not in economic activities per se but in their maintenance of traditionally oriented households under conditions of culture contact which necessitated that men be away from home for considerable periods" (Helms, p. 197). Both Gough's and Helms' work is foreshadowed by R. F. Murphy, "Matrilocality and Patrilineality in Mundurucu Society," American Anthropologist 58 (1956): 414-35, which posits a shift from patrilocality to matrilocality among the Mundurucu probably owing to "pressures which increased the importance of maintaining the integrity and continuity of the female household work group" (Murphy, p. 430). An important part of the Mundurucu adaptation during the period of transition from patrilocality to matrilocality was a long period of symbiosis with Europeans at the periphery of their territory that entailed male absence from the heartland. 
Modern Minangkabau society does not conform to the prevalent scholarly stereotype of it, and it is conceivable that matriliny affects different men in different ways. Moreover, any marriage has a developmental cycle, and a man's situation and his experience of that situation may vary as the domestic cycle develops and his personal adjustment matures.

Today in Koto Anu, not all men marry into extended households; some immediately move into newly built or rented houses. Even if the early stage of marriage is characterized by life in a somewhat extended household, the couple will often quickly emancipate themselves by building or renting a house of their own (or, for their children, as they most often say).

Marriages, for a significant proportion of the population, are brittle, especially in the early stages, but most people have married only once. For a man, the longer his marriage endures the more secure his entrenchment in his "children's house" (i.e., his wife's house, or the house he has built for his wife and children), until in middle age, his attachment to his parental house is characterized by occasional visits only. The entrenchment of the longestablished urang sumando (in-marrying male) may be accompanied by the retreat of the mamak rumah (the matrilineal kinsmen of the wife charged with overseeing the welfare of her household). Relations between the in-marrying male and the matrikin of his wife once this dominance conflict has been resolved in a mutually congenial balance of authority, can mature into a relationship of affection and trust to the point where the husband largely takes over the responsibilities of the mamak rumah and may even be referred to, in Koto $\mathrm{Anu}$, as the tungganai rumah, the mamak rumah's former appellation.

Although the husband is essential for procreation (as proponents of the particular theory will have it), in most cases, his importance to his wife and children is more far-reaching than that. It is only in the richer families, where heavy work in the rice fields may be jobbed out to wage-laborers, that the husband is dispensable to the domestic economy of his wife. In all other cases, his labor is essential for the heavy work in the fields, and his side-activities (fishing, stock-raising, woodcutting, tailoring, barbering, or whatever) are important supplements to the income of the self-sufficient domestic economy, and are, traditionally, the means by which the children's education is paid for and any luxuries above the subsistence level are afforded. In his absence, during a temporary marital breakdown, at divorce, or upon his death, these responsibilities fall to a matrikinsman of the wife (her brother, say) who will have the same responsibilities in his wife's household and will be likely to find their duplication onerous. The reconciliation of the couple, or the remarriage of the divorcee or widow, then becomes quite pressing.

\section{Matrilocality in Koto Anu}

Matrilocality in one sense or another is the rule in Koto Anu. Even what might be termed neolocality may, there, be understood as a form of matrilocality. With few exceptions, land in the residential part of Koto Anu is mostly ancestral property (harato pusako). When a new house is built for a couple, it is, therefore, usually built on the family property of the bride close to the other houses of her matrilineage. In this way, a newly built house occupied by an incipient nuclear family still represents matrilocal residence for the bride. When a new house is built on newly bought land, the land will, in general, be bought by the parents of the bride, and is thus a candidate for low ancestral property because it is destined to be inherited in a way that favors the daughters/wife. Even when it is bought by the newly wed husband or the husband and wife together it can still be a candidate for low ancestral property according to the sentiment that daughters are favored in the inheritance of real property. When the change to neolocality in this qualified sense occurs some time after 
marriage, it is often the earnings of the husband or the joint earnings of husband and wife that finance the actual construction. A house built in this way on matrilineally entailed land is known as a gabungan investment (a "combined" investment of the entailed land of the wife and the earnings of husband or husband and wife). Upon divorce, the former husband loses whatever investment he has made in the house because of the impossibility of distributing the investment between the divorced couple.

\section{The Design of Houses}

The traditional rumah gadang (big house) is rare in Koto Anu. All were built around the turn of the century and most are falling into serious disrepair and are being abandoned. Since the turn of the century succeeding fashions of householding have held sway, but all, in one way or another, fulfill functional prerequisites of Minangkabau house architecture that seem to be immutable and no different from those that dictated the organization of the rumah gadang.

The traditional "big house" had a row of small bedrooms each opening out onto a large sitting/dining area. The kitchen was tacked on behind and lower than the house as a separate structure. There was no bathroom, ablutions being accomplished in the nearest stream. Every successive wave of fashion in housebuilding obeys the same imperatives. The small bedrooms, meant for married couples, always open out serially into a larger living area. The kitchen is behind the house, conceptually separate, and lower than the rest of the house. There is generally no bathroom. The most recent style of home architecture is obviously influenced by urban styles of architecture and contains a bathroom and lavatory, but these are ignored in favor of the nearest public ablution sites in a stream or at specially constructed public bathing places served by a stream. When several domestic groups (urang sa-pariuak) reside in one house, the rule is still matrilocal and uxorilocal. Unattached and adolescent males sleep away from the house with their peers to distance themselves from adolescent girls, unmarried women, and in-marrying males other than their father. These rules often appear to be broken, but breaches of the rules are always very temporary, covering an interim period in the reshuffling of residence patterns or to accommodate short-term visitors from the rantau.

\section{Residence Structure and the Domestic Cycle}

There are two modes of residence for the newly married couple in Koto Anu. In the first, the husband will come to live in a household already established by the bride's parents and composed of the bride's mother and/or married sisters and their husbands and children and often certain of the bride's unmarried sisters and preadolescent brothers and nieces and preadolescent nephews. The composition of such a household can vary considerably from instance to instance and can alter radically in a short time. A household established on this matrilocal basis is frequently depleted by death and migration to the extent that what starts as such a household may come to resemble a second residence pattern. A married couple, when their finances permit, at the time of marriage or some years after, may move into a house of their own, either built by them or rented, or simply one of the vacant houses belonging to the wife's lineage. This household, in turn, through the accretion of kin-a widowed mother, a spinster sister from the mother's house, an infant nephew or niece, a newly married daughter and her husband and the latter's children-can come to resemble the shallow stem family or, in time, the somewhat extended household to which a couple might adhere according to the first pattern. The developmental histories of the two kinds of household may be quite different although structurally they are indistinguishable. 
Some writers on Minangkabau recognize a unidirectional trajectory of change towards westernization or modernization in residence patterns, the range of existing household types being, at one extreme, vestiges of tradition and, at the other extreme, omens of the future form of Minangkabau society. Thus, according to a Mingankabau writer, ${ }^{27}$ Minangkabau marriage is undergoing a development from (1) semenda bertandang ("visiting" husband) to (2) semenda menetap (the husband who "stays put" in his wife's matrilineal house) through to (3) semenda bebas (the "free" husband living alone with his wife and children). Note that the particular theory of matriliny refers to only the first two of these three patterns of residence.

However, all three "stages" are exemplified in Koto Anu today. Syafnir's stages (1) and (2) correspond to the first mode of residence identified in this study (although they are two distinct phases of a marriage), and stage (3) corresponds to the second mode. I have observed that mode two can develop into more durable unions with time (i.e., into Syafnir's stage [2]). Thus all marriages have an impetus that impels them through a developmental cycle resembling Syafnir's historical progression, and all families have a conservatism from which the cycle can start all over again from stage (3). It is the progression in individual family histories that gives rise to the widespread conviction that there is an analogous historical progression operating over a much longer period of time. What this widely diffused view ignores is that potential stage (1) houses are continually coming into being from households that initially conformed to stage (3). There may or may not be a gradual winding down of this process in favor of a special form of neolocality limited by the matrilineal tenure of house land. My impression is that there is indeed such a winding down but that it is not because of any vaporous influence such as modernization and is owing to a dramatic shift in the demographic structure of the nagari population. This idea will be discussed further. ${ }^{28}$

\footnotetext{
27 Syafnir Abunain et al., Adat dan Upacara Perkawinan Minangkabau (Kantor Pembinaan Permuseuman Perwakilan Departmen P. dan K., Padang, West Sumatra, 1973), pp. $18 \mathrm{ff}$.

28 Residence of Bachelors. In some villages of West Sumatra boys no longer sleep in surau (prayerhouses) or rumah pareman (bachelors' houses). But in Koto Anu in 1974-1975 many, but by no means all, did. A boy would first start to sleep occasionally in the surau at about age seven, when he first started to learn to recite the Koran, spending the night following his lesson there. As adolescence approached, some boys would move permanently to the surau; others would not. The ages of bachelors who slept in their parental houses ranged to about twentyfive years. Some divorced men also chose to sleep in the house of one of their matrikin rather than in a surau. Males who did sleep in a surau came from all household types. Those who slept at home, however, did so only under certain conditions, that is, where they did not have any adolescent or unmarried adult sisters or female cousins at home, and where there were no urang sumando (in-marrying males) other than their own father, whether a new husband of their mother or a husband of one of their aunts, sisters, or cousins. In households where these conditions did not prevail, friends and cousins of the boy or young man might come to spend the nights, in response, it seems, to the aforesaid conditions in their own homes. The few boys who went to sleep in the surau when these conditions did not prevail would have done so to accompany specific friends or cousins. There was a frequently articulated rule to the effect that unmarried males should sleep away from home. (It was considered mildly anomalous that I, being unmarried, should sleep in the house of the headman's wife, and I eventually moved with two others to an empty surau.) But this rule did not seem to determine when a boy would move to the surau or rumah pareman nor did the frequent taunts of his peers that he was "sleeping with his mother" seem to outweigh the advantages of sleeping at home when this was possible. To the rule that bachelors should sleep in a bachelors' residence, there seems to be a countervailing sentiment expressed by mothers in particular that boys should sleep at home. It is now considered old-fashioned for them to sleep in the surau. If, as pointed out in this article, the trend has been toward less extended households, then the conditions that would make a boy want to move to a surau are occurring less frequently, and a growing proportion are thus enabled to choose sleeping at home. The developing norm seems to be a response to the emerging practice, which is itself dependent on demographic developments.
} 


\section{Objections to Particular and General Theories of Matriliny}

In light of the above ethnographic considerations, my objections to both the particular theory of Minangkabau migration and the general theory of matriliny can be seen to be realistic and not simply academic.

Most Koto Anu men have not grown up under the conditions described in the particular theory linking marantau with Minangkabau social organization, yet migration has not ceased nor is it likely to cease as a result. On the other hand, a relatively large proportion of men have always chosen to stay on in the nagari, especially at a former time when the conditions described by the particular theory may have prevailed or been more common. Men do occupy a peripheral position in Minangkabau society by comparison with some other societies, but they are not as starkly detached from the core as many folk and scholarly commentators would have it; they do not experience their peripherality in a uniform way; and they do not all experience their peripherality as stressful. Moreover, the theories alluded to fail to clarify why stress in Minangkabau is responded to by migration rather than in some other way.

The general theory, insofar as it is a theory of the peripherality of men in matrilineal societies, is thrown into question by a refined look at modern Minangkabau; and insofar as it is a theory of the centrality of women, it is also interrogated by the Minangkabau case. Women in Minangkabau do not experience a uniform centrality; many are positively disadvantaged by the system of inheritance and tenure of land in a way that encourages them to seek their livelihood outside the nagari, as I tried to show.

A view of Minangkabau social structure that does not take folk models at their face value, that looks at a wholly contemporary situation, that admits a variable response to the apparent limitations of social norms, and that examines the possible pressures to migrate on women allows one to arrive at a different theory of Minangkabau migration than the widely promulgated scholarly orthodoxy.

\section{Men, Women, and Migration}

Rather than a push on men from within the nagari, it could well be argued that, in certain specifiable cases, there is more of a pull on them from the rantau and a push on their respective spouses from within the nagari.

Young men are particularly prone to a mystique of marantau perpetuated by the occasional spectacular success of individual emigrants and gilded tales of the opportunities to be had in the rantau. Many of them have had more or less father-absent childhoods, and even if the paternal generation may not have succeeded as splendidly as they had hoped, there is always the dream that their children might prosper where they had not. As his peers disappear into the rantau, the adolescent male is likely to find that the balance of his significant others is not to be found abroad: his security circle is there as are the people who are going to help him succeed in life and recuperate a status often perceived to have been damaged through social processes at home, especially through the process of inheritance of ancestral lands.

For permanent migration to occur, the push on the woman and the pull on the man must complement each other in the joint enterprise of marriage. It is the conjugal pair and its dependents, in this era, which are jointly responsive to whatever the causative or facilitating circumstances are surrounding the decision to migrate, and which must be able to hold their own in the often very difficult conditions in the cities of Indonesia. 
Some couples will be marginally responsive to these pressures, either because the wife is only weakly "pushed" or the husband is only weakly "pulled." These are the minority of couples who spend some years oscillating between residence in the rantau and residence in the nagari. Others, a substantial minority, will not respond at all, having found that they are able to carve out a niche in the nagari that compares favorably with their perceived prospects in the rantau.

The adolescence and early adulthood of many males is characterized by a coming and going between home and abroad, but this ambivalence will, in the majority of cases, be resolved at marriage. The youthful marantau period of males may thus serve an important function as a testing period to find out if they can respond to the opportunities that await them in Indonesia's cities. It is the unmarried male who feels most acutely the peripherality of his gender in Minangkabau, and this only in combination with other factors may be functional for migration.

Earlier migration may have been temporary and mainly of males, and conditions in the nagari may well have corresponded with a certain classical view of Minangkabau society. Out of this ancient situation the present form of marantau may have gradually developed in a continuously changing relationship simultaneously with the emergence of the present form of Minangkabau social organization. But a refined view of the relationship between social organization and migration calls for a description of Minangkabau society that recognizes that not all men and not all women find themselves in the same position in that society and that recognizes both the male's potential for deep involvement in village life as well as the female's potential for detachment from it.

\section{Change and Continuity}

Because of the lack of fit between reconstructions of precontact Minangkabau (themselves derived from the accounts of folk theorists) and actual ethnographic situations, early Dutch authors spoke of the degeneration of the traditional system. Modern authors prefer to speak of "change and continuity." Like all societies, Minangkabau is constantly changing, and I have been privileged to observe sporadically the process of evolution over more than a decade. Minangkabau is indeed in a process of change, but contemporary change may simply be in the direction of a deepening and irretrievable stagnation.

\section{Agricultural Involution and Devolution}

The varying ability of men to respond to the pull of the rantau and the varying situations of women within the nagari ensure a flexible response to economic and demographic pressures. So too does the Koto Anu agricultural adaptation.

Although Minangkabau is Indonesia's region of densest population concentration outside Java, agricultural involution in Minangkabau may never have reached the intensity found in Java. ${ }^{29}$ In general, rice is planted only once a year. A minority of farmers have always planted in the "off season" (taun salek, literally, "the in-between year or season"). The proportion who do so varies from year to year.

The crop planted in the sawah (irrigated fields) is not always rice. Tobacco and beans and other annual crops may also be planted there. Recently there has been a dramatic increase in the price of chili peppers and many rice fields have been devoted to growing them

\footnotetext{
${ }^{29}$ See C. Geertz, Agricultural Involution (Berkeley: University of California Press, 1963).
} 
in the off season. The yield in money terms is the same as that for rice, but the work involved is much lighter, indicating one aspect of devolution.

The recent acceptance of fertilizers, pesticides, herbicides, and mechanical hoes, whatever their respective pros and cons, may be yet another index of a form of agricultural devolution.

But even many years ago, Koto Anu was capable of an involutionary/devolutionary flexibility. Variability over the last fifty years in the use of labor-intensive practices in preparing the rice fields for planting, in germinating, planting, weeding, and harvesting the rice crop all point to an ongoing flux in the involution/devolution response.

Of interest also from the point of view of agricultural devolution is that Koto Anu has extensive irrigated rice fields that were only spasmodically, and are nowadays not at all, cultivated. These fields are located on the steeper slopes furthest from the lake and abutting the forest. They would have required enormous inputs of labor to establish and were pioneered many years ago. The reason for not using them now is given as the fact that they are vulnerable to pests emanating from the forest (such as pigs and rats) and would require continuous supervision when the crops were ripening. The fact that the labor is not available to supervise them is another aspect of devolution.

Implicated in the involution/devolution dialectic are the many other economic activities in Koto Anu indicated earlier in this article. Of significance also are currents in the national economy that act in some measure on the intensity of migration and that are the greatest determinant on demographic pressures within the nagari. The nagari always has the possibility of reinvolution should the intensity of migration tail off in response to constraints originating in the rantau or should large numbers of emigrants decide to return to the nagari.

\section{The Integrity of the Nagari Population}

The site of cultural differentiation within the Minangkabau region is the nagari. The five hundred or so nagari are differentiated in dialect, in custom, in village-level political structure, and in ecological and economic adaptation. They are also, by and large, endogamous. The mosaic of cultural differentiation across the Minangkabau countryside and the boundedness of its constituent communities is quite remarkable when one considers that this integrity is preserved in important respects even as a large proportion of the populations of villages becomes dispersed and intermingled in the cities of Indonesia.

Each nagari has its home adaptation: one is known for its weaving and woodcarving, another for its cabbages, one for its ironware, one for its silverware, one for its imitation goldware, and the neighbor of the latter for the marketing of that imitation goldware. Most nagari are distinctive by virtue of a unique mix of agricultural activities. Koto Anu is distinctive by virtue of its unusual emphasis on rice production, owing to its ecological situation.

In addition, each nagari is marked by a distinct specialization or combination of specializations among its rantau segment. Thus the village mentioned because of the renown of its silversmiths is remarkable for the large number of higher-echelon public servants it has produced; nagari Maninjau is said to have produced many booksellers in the rantau, and so on.

Of the adult male Koto Anu population in the rantau, 25 percent are tailors, 23 percent are traders in cloth and clothing, 13 percent are barbers, 8 percent are students, 5 percent are civil servants, 4 percent are farmers, 3 percent are carpenters, 3 percent are teachers, and 2 
percent work for Caltex and Pertamina in Pakan Baru. The remainder comprises craftsmen of various kinds, trishaw pedalers, sailors, sawmen, restauranteurs, bus and taxi drivers, policemen and militia, rubber plantation workers, laborers, and a small number of highly educated people in specific professions. The same proportions would not hold for other nagari in West Sumatra, and the complete range of rantau occupations is not represented in Koto Anu, which indicates that the apportionment of occupations in the Minangkabau diaspora is not random but orderly in relation to nagari of origin.

Most Minangkabau nagari are endogamous to some degree. Even where the level of endogamy within the nagari is not high, there is still a degree of local endogamy embracing a relatively small area. Koto Anu is highly endogamous. In Koto Anu it is said that a man who marries an outsider has been "bewitched" (tamakan, also meaning "poisoned"), and such marriages, although not forbidden, are regretted. The same sentiments do not apply to women who have married outsiders, for according to Minangkabau rules of residence, their husbands can always come back to the village to stay. Of the last marriages of people in my census of 1974-1975, 84 percent were with people from Koto Anu, 4.5 percent were with people from one of the two adjacent nagari, 1.2 percent were with people from the other adjacent (but more distant) nagari, 4.7 percent were with people from other parts of the West Sumatran Highlands, 3.8 percent were with people from the coastal parts of the Minangkabau heartland, 1.2 percent were with people from other parts of Sumatra, 0.5 percent were with people from Java, and the remaining 0.2 percent were with people from elsewhere.

Of all marriages, 78 percent occurred in the nagari, although of these probably half were actually contracted among the Koto Anu community in the rantau. Thus only 22 percent of all last marriages were effected in the rantau and some of these would have actually been contracted in the nagari.

The closure of the nagari with regard to marriage transactions is, of course, mimicked by other forms of communication. And the social organization of the nagari is reflected in important respects in the rantau segment of the population. The mesh of the social network in the rantau is significantly closed for women owing to the matrilateral asymmetry in choice of migratory destination alluded to previously. But is is also closed for men simply because of endogamy. For men there is more expression of choice in initial migratory destination, although secondary and tertiary movements may be conditioned by their wives' needs to be near kinswomen. ${ }^{30}$ The mesh of the rantau network is, therefore, more open for men than for women, but still closed on a communitywide basis. Consanguinity is important for women both in the nagari (because of the system of land tenure) and in the rantau. Consanguinity does not take on the same importance in the nagari for men, and in the rantau clientage is acknowledged to be of greater importance, although clientage will be sought from the base of the security circle of villagers in the rantau. Therefore, the more open mesh of men's over women's networks in the rantau is simply the generalization of a trend that is already apparent in the nagari.

As an entity in its own right, the rantau segment of the Koto Anu population retains a certain integrity that is relatively independent of social processes at home. It is apparent

\footnotetext{
${ }^{30}$ It has been widely noted that interaction in kinship networks in urban settings seems to assume a matrilateral emphasis, and it is argued that this is economically functional for urban dwellers. For India, see S. J. Vatuk, "Trends in North Indian Urban Kinship," Southwestern Journal of Anthropology 27 (1971): 287-307. For North America see J. J. Poggie and P. J. Pelto, "Matrilateral Asymmetry in the American Kinship System," Anthropological Quarterly 42 (1969): 1-5.
} 
when talking to villagers returning from the rantau that the Koto Anu contingent in any center, however small or however large, forms a self-conscious and solidary community. The solidarity of Koto Anu communities, they say, is even more apparent in the rantau where one is surrounded by strangers than it is in the village where factionalism is prevalent. In the nagari there is only one voluntary association, the farmers' cooperative, but in the rantau there are many associations that one may belong to, both permanent and formal as well as transitory and informal.

\section{Demographic Changes}

In 1986, after eleven years, I undertook a further short period of fieldwork in Koto Anu. I took the opportunity to resurvey just one of the six clans, using the same genealogies that had been collected in 1974-1975 as a starting point in interviews. The results are presented in table 1.

Table 1. Distribution of Village and Diaspora Populations of Koto Anu

\begin{tabular}{|c|c|c|c|c|c|c|c|c|c|c|c|c|}
\hline & \multicolumn{6}{|c|}{ 1974-1975 } & \multicolumn{6}{|c|}{1986} \\
\hline & \multicolumn{2}{|c|}{ Male } & \multicolumn{2}{|c|}{ Female } & \multicolumn{2}{|c|}{ Total } & \multicolumn{2}{|c|}{ Male } & \multicolumn{2}{|c|}{ Female } & \multicolumn{2}{|c|}{ Total } \\
\hline & (No.) & $(\%)$ & (No.) & $(\%)$ & (No.) & $(\%)$ & (No.) & $(\%)$ & (No.) & (\%) & (No.) & $(\%)$ \\
\hline \multicolumn{13}{|l|}{ Subclan A } \\
\hline Nagari & 40 & 24 & 49 & 30 & 89 & 54 & 40 & 17 & 37 & 16 & 77 & 32 \\
\hline Rantau & 37 & 22 & 40 & 24 & 77 & 46 & 83 & 35 & 78 & 33 & 161 & 68 \\
\hline Total & 77 & 46 & 89 & 54 & 166 & 100 & 123 & 52 & 115 & 48 & 238 & 100 \\
\hline \multicolumn{13}{|l|}{ Subclan B } \\
\hline Nagari & 30 & 25 & 32 & 27 & 62 & 52 & 19 & 14 & 22 & 16 & 41 & 30 \\
\hline Rantau & 34 & 28 & 24 & 20 & 58 & 48 & 48 & 36 & 45 & 34 & 93 & 70 \\
\hline Total & 64 & 53 & 56 & 47 & 120 & 100 & 67 & 50 & 67 & 50 & 134 & 100 \\
\hline \multicolumn{13}{|l|}{ Subclan C } \\
\hline Nagari & 61 & 23 & 74 & 28 & 135 & 51 & 38 & 11 & 52 & 16 & 90 & 26 \\
\hline Rantau & 70 & 26 & 60 & 23 & 130 & 49 & 115 & 34 & 132 & 39 & 247 & 74 \\
\hline Total & 131 & 49 & 134 & 51 & 265 & 100 & 153 & 45 & 184 & 55 & 337 & 100 \\
\hline \multicolumn{13}{|l|}{ Subclan D } \\
\hline Nagari & 56 & 22 & 62 & 25 & 118 & 47 & 47 & 13 & 56 & 16 & 103 & 29 \\
\hline Rantau & 69 & 28 & 62 & 25 & 131 & 53 & 138 & 39 & 117 & 32 & 255 & 71 \\
\hline Total & 125 & 50 & 124 & 50 & 249 & 100 & 185 & 52 & 173 & 48 & 358 & 100 \\
\hline \multicolumn{13}{|l|}{ Subclan E } \\
\hline Nagari & 47 & 22 & 62 & 29 & 109 & 51 & 19 & 8 & 31 & 12 & 50 & 20 \\
\hline Rantau & 60 & 28 & 45 & 21 & 105 & 49 & 93 & 38 & 104 & 42 & 197 & 80 \\
\hline Total & 107 & 50 & 107 & 50 & 214 & 100 & 112 & 46 & 135 & 54 & 247 & 100 \\
\hline \multicolumn{13}{|l|}{ Subclan F } \\
\hline Nagari & 21 & 20 & 24 & 23 & 45 & 43 & 14 & 10 & 18 & 13 & 32 & 23 \\
\hline Rantau & 33 & 31 & 27 & 26 & 60 & 57 & 55 & 41 & 49 & 36 & 104 & 77 \\
\hline Total & 54 & 51 & 51 & 49 & 105 & 100 & 69 & 51 & 67 & 49 & 136 & 100 \\
\hline \multicolumn{13}{|l|}{ Whole Clan } \\
\hline Nagari & 255 & 23 & 303 & 27 & 558 & 50 & 177 & 12 & 216 & 15 & 393 & 27 \\
\hline Rantau & 303 & 27 & 258 & 23 & 561 & 50 & 532 & 37 & 525 & 36 & 1,057 & 73 \\
\hline Total & 558 & 50 & 561 & 50 & 1,119 & 100 & 709 & 49 & 741 & 51 & 1,450 & 100 \\
\hline
\end{tabular}


In the intervening years, the rantau segment of the population has increased and the rantau/nagari population ratio has increased dramatically. There has been a large decrease in the nagari population. But, owing to the markedly different characteristics of the two segments, the increase in the rantau segment can be explained by births occurring in the rantau, and the decrease in the nagari can be the result of mortality internal to the nagari and not necessarily to any increase in the rate of emigration. The nagari population has become significantly more aged and more feminine since 1974-1975. The same picture is presented consistently across the six subclans of this clan, and there is no reason to suppose that any of the other five clans in Koto Anu would present a different picture.

Nowadays, households are smaller than they once were, and domestic units (urang supariuak) are dispersed in a less concentrated way across the available housing. This process has been facilitated by an increased rate of house construction financed from the rantau over the last decade. In 1974-1975 the majority of bachelors slept in prayer-house cum bachelor houses (surau) or empty houses termed rumah pareman (from the Dutch vrijman). Now most of the surau are falling into serious disrepair and are being replaced by a different concept in prayer-houses termed musholla, which is no longer a refuge for the peripheral, unattached male. However, I argue that changes in residence patterns are entirely owing to demographic changes, especially in relation to available housing, and that residence is still ordered by the same cultural principles as before.

Residence for married couples is still matrilocal and uxorilocal or neolocal in the qualified sense. Bachelors still avoid sleeping in houses where they have adolescent or unmarried adult female relatives or in-marrying males other than their fathers. As in previous decades, these patterns are only varied for short periods when there is a need to accommodate people visiting from the rantau or as a purely temporary measure.

\section{Changes in the Nagari/Rantau Relationship}

In the last decade there has been a decrease in the degree of nagari endogamy within the total nagari plus rantau population. More marriages are contracted nowadays with nonKoto Anu and even non-Minangkabau people. The author believes that this is a consequence of the shift in the center of gravity of the total population in favor of the rantau, and it is indicative of a growing independence of the rantau segment for the purpose of such things as contracting marriages.

Breakdown in endogamy may be indicative of a degree of erosion of the "integrity" of the total population that I mentioned earlier. This is happening throughout the Minangkabau population: the diaspora is becoming increasingly independent of and detached from the homeland. In fact, Minangkabau people, or their children and grandchildren, are increasingly becoming absorbed into other regional and ethnic identities.

It was apparent during the re-census of one clan that there has been considerable redistribution of the rantau segment across the towns of Sumatra and Java. The bigger centers have in recent years developed a gravitational pull that attracts migrants not only immediately from Koto Anu but also secondarily from the less favored smaller towns. In particular, there has been a dramatic increase in the proportion of the Koto Anu population to be found in Jakarta and the larger cities of Java.

The nagari itself is relatively more prosperous than it was a decade ago owing to a complex of factors. There may be less pressure on resources than before due to emigration. But more important is the volume of money and goods sent back from the rantau from married children who are at an age when the flow of wealth between parents and children 
has begun to reverse itself in the parent's favor. This flow has been made possible by a generalized increase in prosperity throughout Indonesia.

It is curious that the breakdown of the integrity of Minangkabau communities is accompanied by an intensification of attempts at revitalization of Minangkabau traditions in the homeland. These efforts are initiated mainly from the rantau. There is an awareness that a whole way of life is disappearing in the countryside. Among the rantau community there is a degree of sentimentalism about the home nagari and a desire to solidify ties at home-a desire that is not disinterested from the point of view of land inheritance. Most recent housebuilding within the nagari has been financed from the rantau by people who look forward to retiring to their villages, although so far few have done so; they are more likely to join the households of one of their children in the rantau.

\section{Summary and Conclusions}

Minangkabau society has probably been highly migratory for a very long time. The Negeri Sembilan in Malaysia were already settled by Minangkabau emigrants five hundred years ago. And migration has probably existed in a functional relationship with matrilocal and matrilineal social organization at home for centuries. Men play a leading role in migration but often are followed to their migratory destination by potential wives, wives, and other kin. However, which women choose to migrate is also influenced by social structural features of the homeland society. ${ }^{31}$

The social determinants of migration acting upon women are different from those said to cause or facilitate male migration and relate directly to the cultural core-the cultivation of rice and the devolution of rice lands.

Other factors identified as facilitating Minangkabau migration are the flexibility of the agricultural involution/devolution dialectic and the corporateness and integrity of the total population of any endogamous community, including its migrants.

The genealogical construction of the community includes ideas about the partibility of inheritance, the implications of fecundity, and the origins of economic inequality. Kinshiprelated concepts in the latter three fields act in concert in determining how land is devolved in the kinship network and in determining how poverty is perceived and explained. Together they are important factors influencing the decision to migrate, and they act principally on women. Therefore, theories of Minangkabau society that relate migration mainly to social factors impinging on men as well as general theories of matrilocal and matrilineal societies that see women as nonmigratory because of the central and sedentary role they play in the spatial organization and economy of the society are both called into question in light of the data offered in this essay.

Minangkabau society has long been described in terms of the changes it and its matrilineal system are undergoing. Finally, it is suggested that the fundamental source of change in modern Minangkabau is demographic, explaining agricultural devolution, the breakdown of the sociological integrity of the community, and changes in residence patterns.

\footnotetext{
31 Marantau is widely understood by ethnographers to have been mainly a male activity in previous eras in Minangkabau. If this is so then my observations of the factors influencing female migration do not apply to earlier decades. However, there can equally have been a male emphasis in reporting by historians, geographers, administrators, and more recently, anthropologists as has been shown in the ethnography of Australia. I find it easy to accept that marantau was always initiated largely by men just as it is today; however, the record is more or less silent about the involvement and participation of women.
} 
